\title{
COMPARATIVE AND CRITICAL ANALYSIS OF KEY ELIGIBILITY CRITERIA FOR VOLUNTARY ASSISTED DYING UNDER FIVE LEGAL FRAMEWORKS
}

\author{
BEN P WHITE, ELIANA CLOSE, LINDY WILLMOTT, KATRINE DEL VILLAR, \\ JOCELYN DOWNIE, JAMES CAMERON, JAYNE HEWITT, REBECCA MEEHAN \\ AND LAURA LEY GREAVES*
}

\begin{abstract}
Eligibility criteria determine a crucial question for all voluntary assisted dying frameworks: who can access assistance to die? This article undertakes a critical and comparative analysis of these criteria across five legal frameworks: existing laws in Victoria, Western Australia, Oregon and Canada, along with a model Bill for reform. Key aspects of these criteria analysed are capacity requirements; the nature of the medical condition that will qualify; and any required suffering. There are many similarities between the five models but there are also important
\end{abstract}

Ben P White, LLB (Hons) (QUT), DPhil (Oxford), Professor of End-of-Life Law and Regulation, Australian Centre for Health Law Research, Faculty of Business and Law, Queensland University of Technology; Eliana Close, BSc (Hons) (Calgary), MA (Oxford), PhD (QUT), Lecturer and Postdoctoral Research Fellow, Australian Centre for Health Law Research, Faculty of Business and Law, Queensland University of Technology; Lindy Willmott, BCom (UQ), LLB (Hons) (UQ), LLM (Cambridge), PhD (QUT), Professor, Australian Centre for Health Law Research, Faculty of Business and Law, Queensland University of Technology; Katrine Del Villar, BA (Hons) (ANU), LLB (Hons) (ANU), PhD (QUT), Postdoctoral Research Fellow, Australian Centre for Health Law Research, Faculty of Business and Law, Queensland University of Technology; Jocelyn Downie, CM, FRSC, FCAHS, BA (Hons) (Queen's), MA (Queen's), MLitt (Cambridge), LLB (U of T), LLM (Michigan), SJD (Michigan), University Research Professor, Dalhousie University, Adjunct Professor, Australian Centre for Health Law Research, Faculty Business and of Law, Queensland University of Technology; James Cameron, BA (Melb), MA (Bioethics) (Monash), JD (Melbourne), PhD Candidate, Melbourne Law School, University of Melbourne; Jayne Hewitt, BN (Flin), LLB (QUT), LLM (QUT), PhD (Griffith), Lecturer, School of Nursing and Midwifery, Research Fellow, Law Futures Centre, Griffith Law School, Griffith University; Rebecca Meehan, BHSc(Pod) (QUT), LLB (Hons) (QUT); Laura Ley Greaves, BSc (Hons) (Imperial), MBBS (Imperial), Australian Centre for Health Law Research, Faculty of Business and Law, Queensland University of Technology.

We disclose that Ben White and Lindy Willmott were engaged by both the Victorian and Western Australian governments to design and provide the legislatively mandated training for doctors involved in voluntary assisted dying. Jayne Hewitt was the project manager for the Victorian training project and Rebecca Meehan, Laura Ley Greaves and Eliana Close were employed on the project. Eliana Close and Katrine Del Villar were also employed on the Western Australian training project. James Cameron was a Senior Legal Policy Officer at the Department of Health and Human Services (Victoria) and developed and implemented the Voluntary Assisted Dying Act 2017 (Vic). Jocelyn Downie was a member of the Royal Society of Canada Expert Panel on End-of-Life Decision-Making, a member of the plaintiffs' legal team in Carter v Canada (Attorney General) [2015] 1 SCR 331, a member of the ProvincialTerritorial Expert Advisory Group on Physician-Assisted Dying and a member of the Council of Canadian Academies Expert Panel on Medical Assistance in Dying. Rebecca Meehan is an employee of Queensland Parliament, but this article only represents her views. Ben White is a recipient of an Australian Research Council Future Fellowship (project number FT190100410: Enhancing End-of-Life Decision-Making: Optimal Regulation of Voluntary Assisted Dying) funded by the Australian government. The authors gratefully acknowledge the research assistance of Emily Bartels. 
differences which can have a significant impact on who can access voluntary assisted dying and when. Further, seemingly straightforward criteria can become complex in practice. The article concludes with the implications of this analysis for designing voluntary assisted dying regulation. Those implications include challenges of designing certain yet fair legislation and the need to evaluate voluntary assisted dying frameworks holistically to properly understand their operation.

\section{INTRODUCTION}

Internationally, voluntary assisted dying ('VAD') is permitted in an increasing number of jurisdictions. In Europe, VAD is legal in certain circumstances in the Netherlands, ${ }^{1}$ Belgium ${ }^{2}$ and Luxembourg. ${ }^{3}$ Further, in Switzerland, ${ }^{4}$ and more recently in Germany, ${ }^{5}$ assisting a person to self-administer lethal medication in certain circumstances has been decriminalised. In the United States of America ('US'), there are now ten states and one district where VAD is lawful, with ten having legalised the practice by passing legislation ${ }^{6}$ and one through judicial decision. ${ }^{7}$ VAD is also permitted in Canada ${ }^{8}$ and Colombia. ${ }^{9}$

1 Wet Toetsing Levensbeëindiging op Verzoek en Hulp Bij Zelfdoding 2001 [Termination of Life on Request and Assisted Suicide (Review Procedures) Act 2001] (The Netherlands).

$2 \quad$ Loi Relative à L'euthanasie 2002 [Act on Euthanasia 2002] (Belgium).

3 Legislation Reglementant les Soins Palliatifs ainsi que L'euthanasie et L'assistance au Suicide 2009 [Legislation Regulating Palliative Care and Euthanasia and Assisted Suicide 2009] (Luxembourg).

$4 \quad$ Schweizerisches Strafgesetzbuch 1937 [Swiss Criminal Code 1937] (Switzerland) art 115: 'Any person who for selfish motives incites or assists another to commit or attempt to commit suicide is, if that other person thereafter commits or attempts to commit suicide, liable to a custodial sentence not exceeding five years or to a monetary penalty'.

5 Bundesverfassungsgericht [German Constitutional Court], 2 BvR 2347/15,ECLI:DE:BVerfG:2020:rs20200226.2bvr234715, 26 February 2020 reported in (2020) BverfG1.

6 Death with Dignity Act, Or Rev Stat $\S \S 127.800-127.897$ (1994) ('Oregon Act'); Death with Dignity Act, Wash Rev Code $\S \S 70.245 .010-70.245 .903$ (2008); Patient Choice and Control at End of Life Act, Vt Stat Ann $\S$ 5281-93 (2013); End of Life Option Act, Cal Health and Safety Code $\S$ 443-443.22 (West 2015); Death with Dignity Act of 2016, DC Code $\S \S 7-661.01-7-661.16$ (2017) (District of Columbia); Colorado End-of-Life Options Act, Colo Rev Stat §§ 25-48-101-25-48-123 (2017); Our Care, Our Choice Act, Haw Rev Stat $\S \S 327 \mathrm{~L}-1-327 \mathrm{~L}-25$ (2018); Medical Aid in Dying for the Terminally Ill Act, NJ Stat Ann $\S \S$ 26:16-1-26:16-20 (West 2021); Maine Death with Dignity Act, 22 Me Rev Stat Ann § 2140 (2019); Elizabeth Whitefield End-of-Life Options Act, NM Stat $§ 3$ (2021).

7 Baxter v Montana, 224 P 3d 1211 (Mont, 2009). Pope argues that VAD is also lawful in North Carolina through a 'standard of care' approach. There is no legislation, regulation or court case that permits VAD, but VAD is not prohibited under current law. See Thaddeus Pope, 'Medical Aid in Dying: Key Variations Among U.S. State Laws' (2020) 14(1) Journal of Health and Life Sciences Law 25, 35.

8 Across Canada through the Criminal Code, RSC 1985, c C-46, ss 241.1-241.4 ('Canadian Criminal Code') and in Quebec also through the Act Respecting End-of-Life Care, RSQ 2014, c S-32.0001. The criteria in these laws are similar but not identical. However, because the federal law applies across the whole of Canada, this article focuses on the eligibility criteria contained in the Canadian Criminal Code.

9 A court decision in Colombia permitted VAD in 1997: Sentence C-239/97, Republic of Colombia Constitutional Court, Ref Expedient D-1490, 20 May 1997, which was followed by government regulations to facilitate the practice in 2015: Ministry of Health and Social Protection, Protocolo para la Aplicación del Procedimiento de Eutanasia en Colombia [Protocol for the Application of the Procedure of 
Australia too has seen law reform in this area. In November 2017, the Voluntary Assisted Dying Act 2017 (Vic) ('Victorian Act') was passed. It came into force on 19 June 2019, permitting VAD in Australia for the first time in 20 years. ${ }^{10}$ This was followed in December 2019 by the enactment of the Voluntary Assisted Dying Act 2019 (WA) ('WA Act'), after an extensive parliamentary debate which followed reviews by a Parliamentary Committee ${ }^{11}$ and a Ministerial Expert Panel. ${ }^{12}$ These laws may herald a shift in political thinking, because despite a long history of unsuccessful attempts of reform, ${ }^{13}$ it appears that the climate in Australia may now be more conducive to change..$^{14}$ As this article was being finalised for publication, Tasmania passed VAD legislation, ${ }^{15}$ there is a Bill before the South Australian ${ }^{16}$ and Queensland ${ }^{17}$ Parliaments, and a Bill is also proposed in 2021 in New South Wales. ${ }^{18}$

Akey policy question for Australian and international legislators when designing such laws is who should be permitted to access VAD. The primary means by which access is regulated is through eligibility criteria. Although generally only a small part of the legislation in terms of the number of provisions, eligibility criteria play a significant role in determining the breadth of VAD laws. Broad eligibility criteria exclude very few individuals from VAD, whereas narrow and tightly constrained criteria can significantly limit access.

This article is the first in a two-part series ${ }^{19}$ that critically analyses the scope and operation of eligibility criteria in five VAD legal frameworks. In particular, the articles consider these two questions: for what medical conditions, and at what stage in the trajectory of those conditions, would a person be eligible to access VAD? While eligibility criteria commonly contain provisions unrelated to a person's health state, such as residency and age requirements, the most contentious

Euthanasia in Colombia] (Report, 2015) <https://www.minsalud.gov.co/sites/rid/Lists/BibliotecaDigital/ $\mathrm{RIDE} / \mathrm{DE} / \mathrm{CA} /$ Protocolo-aplicacion-procedimiento-eutanasia-colombia.pdf>.

10 VAD was briefly permitted in the Northern Territory by the Rights of the Terminally Ill Act 1995 (NT) but this legislation was overturned later by the Euthanasia Laws Act 1997 (Cth).

11 Joint Select Committee on End of Life Choices, Parliament of Western Australia, My Life, My Choice (Report No 1, 23 August 2018).

12 Ministerial Expert Panel on Voluntary Assisted Dying, Department of Health (WA), Final Report (Report, June 27 2019) ('MEP Report').

13 For a detailed discussion of the history of attempts at law reform in Australia, see Lindy Willmott et al, '(Failed) Voluntary Euthanasia Law Reform in Australia: Two Decades of Trends, Models and Politics' (2016) 39(1) University of New South Wales Law Journal 1. See also updated data in Ben White and Lindy Willmott, 'Future of Assisted Dying Reform in Australia' (2018) 42(6) Australian Health Review 616 ('Future of Assisted Dying Reform').

14 White and Willmott, 'Future of Assisted Dying Reform' (n 13) 618-19.

15 End-of-Life Choices (Voluntary Assisted Dying) Act 2021 (Tas). This will take effect in October 2022, after a prescribed implementation period: s 2 .

16 Voluntary Assisted Dying Bill 2020 (SA).

17 Voluntary Assisted Dying Bill 2021 (Qld).

18 Michael Koziol, 'Fresh Bid to Legalise Assisted Dying Set to Test NSW Government', Sydney Morning Herald (online, 13 December 2020) <https://www.smh.com.au/politics/nsw/fresh-bid-to-legalise-assisteddying-set-to-test-nsw-government-20201209-p56m2t.html>.

19 The second article is Ben P White et al, 'Who is Eligible for VAD? Nine Medical Conditions Assessed Against Five Legal Frameworks' (2022) 45(1) University of New South Wales Law Journal (forthcoming) ('Who is Eligible for VAD?'). 
discussion when debating eligibility under VAD laws has been in relation to when, and with what medical conditions, a person could seek access to VAD. ${ }^{20}$

This first article undertakes a critical analysis of the eligibility criteria outlined in five selected models of VAD, with a particular focus on those criteria that are relevant to a person's health state. Key aspects of those criteria are: the nature of the medical condition or illness a person must have, and the requirement to retain decision-making capacity when seeking VAD. The criteria in three Australian models have been chosen for review: the Victorian Act, the WA Act, and a model Voluntary Assisted Dying Bill 2019 ('Model Bill') ${ }^{21}$ recommended by the Queensland Parliamentary Inquiry considering VAD as the proposed basis for reform. ${ }^{22}$ The Victorian legislation has served as a basis for both the WA Act and the Model Bill, although both incorporate important differences.

Additionally, the review includes two other important common law comparators. ${ }^{23}$ The first is Oregon's Death with Dignity Act 1994 ('Oregon Act'). ${ }^{24}$ It is the original legislation in the US and has largely been copied by other states in that country. It was also cited as an important departure point when designing the Victorian model. ${ }^{25}$ The second law considered is Canada's federal law about VAD (called 'MAiD': medical assistance in dying), which is contained in its Criminal Code ('Canadian Criminal Code'). ${ }^{26}$ Shared legal heritage means Canada is a

20 For example, in Victoria, the debate on the eligibility criteria ranged over people with neurological disease, an insulin dependent diabetic who decides to stop taking insulin, renal disease, terminal cancer, people with disabilities, loneliness, incontinence, autism and mental illness: Victoria, Parliamentary Debates, Legislative Council, 21 November 2017, 6216-24, 6232-9. In Western Australia, the debate on the eligibility clause was briefer, but canvassed a person with gangrene who refuses amputation and a diabetic who refuses insulin (Western Australia, Parliamentary Debates, Legislative Council, 26 November 2019, 9199-201), as well as people with autism and mental illnesses such as schizophrenia, anorexia and depression (Western Australia, Parliamentary Debates, Legislative Council, 22 October 2019, 7978-9 (Rick Mazza)).

21 Ben White and Lindy Willmott, 'A Model Voluntary Assisted Dying Bill' (2019) 7(2) Griffith Journal of Law and Human Dignity 1 ('Model Bill').

22 Health, Communities, Disability Services and Domestic and Family Violence Prevention Committee, Parliament of Queensland, Inquiry into Aged Care, End-of-Life and Palliative Care and Voluntary Assisted Dying (Report No 34, 31 March 2020) 105, 'Recommendation 1' ('Queensland Parliamentary Report').

23 We note that the New Zealand Parliament passed its End of Life Choice Act 2019 (NZ) in late 2019 (which would only take effect if approved by a public referendum, as subsequently occurred in late 2020). However, this occurred only after this analysis in this article was finalised and accordingly, we will not consider this Act further. Also not included are the European models and Colombia. This is because these jurisdictions are culturally more distinct from Australia than other common law countries, and their laws operate within quite different legal systems.

24 Oregon Act, Or Rev Stat $\S 127.800-127.995$ (1994).

25 For example, in relation to the eligibility criteria: preference for self-administration at a time of the person's choosing without a medical practitioner needing to be present; a prescribed waiting period before VAD can be accessed; review and reporting: Legal and Social Issues Committee, Parliament of Victoria, Inquiry into End of Life Choices (Final Report, 9 June 2016) 217-18, 228 ('LSIC Report'). There are also numerous references to similarities between the Oregon Act and the proposed Victorian law in the Ministerial Advisory Panel on Voluntary Assisted Dying, Department of Health and Human Services (Vic), Final Report (Report, 31 July 2017) ('MAP Report'). See examples just in relation to the eligibility criteria: at $53,55,56,63,69$.

26 Canadian Criminal Code, RSC 1985, c C-46, ss 241.1-241.4. The Canadian law has undergone various iterations (including through amendments made through Bill C-14, An Act to Amend the Criminal Code 
natural comparator for Australia when considering law reform. ${ }^{27}$ Canada's MAiD law has been considered, and Canadian experts consulted, in Australian reviews of $\mathrm{VAD},{ }^{28}$ for example, in respect of its terminology requiring the person's medical condition to be 'incurable', ${ }^{29}$ and in relation to the requirement of unbearable or intolerable suffering. ${ }^{30}$

After critically analysing each of the varying approaches to eligibility, this article undertakes a comparative analysis of the five jurisdictions to identify important areas of similarity and difference. Although this work establishes the foundation for the consideration of medical conditions that follows in the second article, this legal analysis is significant in its own right and has implications for designing VAD regulation, which are identified in Part IV.

The second article then applies this analysis to evaluate whether different medical conditions would be eligible for VAD under the five regimes. These conditions are: cancer (specifically colorectal cancer), motor neurone disease, chronic obstructive pulmonary disease, chronic kidney disease, dementia (specifically Alzheimer's disease), anorexia, spinal cord injury, Huntington's disease and frailty. This diverse group of conditions was chosen with a view to illustrate how the various eligibility criteria would apply in a range of settings. Regard was had to considerations such as those conditions most likely to be relied upon to access VAD, common causes of death in Australia, and conditions in the literature that have sparked controversy about access to VAD.

The analysis in the second article demonstrates how changes in the framing of eligibility criteria can have an impact on who is included or excluded from accessing VAD, and at what point this access may be possible in their illness trajectory. This has implications for law reform, for example, when certain conditions may be seen by the public as important in the case for allowing VAD, but people with those conditions would not be eligible for VAD under the law as drafted. Another conclusion from this research is that concrete thinking is needed when designing VAD laws. While criteria can be considered in the abstract, it is this practical exercise of ascertaining where eligibility criteria will draw lines that is critical. While these decisions have been made for Victoria and Western Australia as their Acts have passed, there is scope to inform the remaining Australian jurisdictions (and indeed other countries) considering VAD reform.

and to Make Related Amendments to Other Acts (Medical Assistance in Dying), $1^{\text {st }}$ Sess, 42 ${ }^{\text {nd }}$ Parl, 2016 ('Bill C-14') and Bill C-7, An Act to Amend the Criminal Code (Medical Assistance in Dying), $1{ }^{\text {st }}$ Sess, $43^{\text {rd }}$ Parl, 2020 ('Bill C-7')).

27 White and Willmott, 'Future of Assisted Dying Reform' (n 13) 618; Stephen Kirchner, Sean Speer and Jason Clemens, 'Policy Reforms in Australia and What They Mean for Canada' (Research Paper, Fraser Institute, 3 December 2013) <https://ssrn.com/abstract=2392622>. See also, particularly in relation to reform of the common law by reference to United Kingdom and Canadian examples: Cook v Cook (1986) 162 CLR 376, 390 (Mason, Wilson, Deane and Dawson JJ); James Allsop, 'Some Reflections on the Sources of Our Law' (2014) 11(4) Judicial Review 365, 371-2.

28 The Ministerial Expert Panel in Western Australia met with four Canadian experts and one from Oregon in drafting the VAD legislation: MEP Report (n 12) 126. Note that Quebec was also considered in Victoria's MAP Report: see above n 25.

29 See, eg, MEP Report (n 12) 33-4 (although they did not adopt this criterion).

30 See LSIC Report (n 25) 217. 
We conclude this introduction with two practical matters. The first is about the scope of analysis of the eligibility criteria. The focus of this two-part series is on the contentious issue of the impact that a person's medical condition has on their eligibility to access VAD. Accordingly, the analysis which follows emphasises criteria such as whether a condition is incurable or likely to cause death, and gives less consideration to other criteria, such as age and residency requirements.

The second practical matter is about terminology. In general, the terminology in relation to VAD used in the Victorian Act (and subsequently mirrored in the Model Bill and the WA Act) will be adopted. VAD therefore includes both 'selfadministration' (where the person takes the prescribed medication themselves, sometimes called physician-assisted suicide or dying) and 'practitioner administration' (where the person is administered the medication by a doctor, or nurse practitioner in Western Australia or Canada, sometimes called voluntary euthanasia). However, when considering Canadian law, the specific defined term used in that law (MAiD) will be used. The article will also refer to a person's 'medical condition'. This is meant in a broad sense, whether that condition is caused by disease, illness, disability, or injury, although we note some VAD laws specifically address these latter concepts.

\section{ELIGIBILITY CRITERIA OF FIVE MODELS}

\section{A Introduction}

This section outlines the eligibility criteria in the five VAD models: three Australian models in chronological order (the Victorian Act, the Model Bill and the WA Act) and then the Oregon Act and the Canadian Criminal Code. As noted above, while all eligibility criteria are noted for completeness, this article focuses on analysing those criteria particularly relevant to determining which medical conditions may provide access to VAD. A final point to note is that the Canadian eligibility criteria have been subject to extensive discussion, including academic commentary specifically aimed at interpreting these criteria, as well as some judicial and now legislative consideration, and this is reflected in the extended treatment of this jurisdiction's law below. By contrast, the Australian models are very new and have been subject to very limited critical analysis to date, and so are addressed more succinctly.

\section{B Voluntary Assisted Dying Act 2017 (Vic)}

The Victorian Act came into force on 19 June 2019 after a planned 18-month implementation period and permits access to VAD after a rigorous process that requires at least three requests from an eligible patient and at least two assessments by qualified and trained medical practitioners. VAD is intended usually to be self-administered, as practitioner administration is permitted only when a person 
is physically incapable of taking or digesting the medication themselves. ${ }^{31}$ The Victorian law was described by the Victorian government at the time of introduction to Parliament as the safest and most conservative VAD model in the world. ${ }^{32}$

Part of this claim is based on the Act's eligibility criteria. Section 9(1) of the Victorian Act outlines the primary eligibility criteria and states that '[f]or a person to be eligible for access to voluntary assisted dying':

(a) the person must be aged 18 years or more; and

(b) the person must-

(i) be an Australian citizen or permanent resident; and

(ii) be ordinarily resident in Victoria; and

(iii) at the time of making a first request, have been ordinarily resident in Victoria for at least 12 months; and

(c) the person must have decision-making capacity in relation to voluntary assisted dying; and

(d) the person must be diagnosed with a disease, illness or medical condition that-

(i) is incurable; and

(ii) is advanced, progressive and will cause death; and

(iii) is expected to cause death within weeks or months, not exceeding 6 months [or 12 months if the disease, illness or medical condition is neurodegenerative $] ;^{33}$ and

(iv) is causing suffering to the person that cannot be relieved in a manner that the person considers tolerable.

Section 9 continues and clarifies that disability and mental illness alone are not grounds to access VAD. ${ }^{34}$ However, the mere fact of a disability or a mental illness will not preclude a person from accessing VAD if the eligibility criteria are met. ${ }^{35}$

\section{Decision-Making Capacity}

Subsection 9(1)(c) requires the person to have decision-making capacity in relation to VAD and this is assessed at multiple points during the process. ${ }^{36}$ If VAD is provided by practitioner administration, capacity is also specifically assessed at that final point in time. For self-administration, capacity is assessed at each stage during the request and assessment process but not at the time of ingestion, as this is done later at a time of the person's choosing and without a practitioner necessarily being present.

31 Voluntary Assisted Dying Act 2017 (Vic) ss 46, 48 ('Victorian Act').

32 Daniel Andrews, 'Voluntary Assisted Dying Model Established Ahead of Vote in Parliament' (Media Release, Premier of Victoria, 25 July 2017) $1<$ https://www.premier.vic.gov.au/voluntary-assisted-dyingmodel-established-ahead-of-vote-in-parliament> ('Andrews Media Release').

33 The words in square brackets have been inserted based on Victorian Act 2017 (Vic) s 9(4).

34 Ibid ss 9(2)-(3).

35 MAP Report (n 25). See 'Ministerial Advisory Panel Recommendation 5' in respect of mental illness: at 80-2. See also 'Ministerial Advisory Panel Recommendation 6' in respect of disability: at 83-5. 
A person has decision-making capacity if they meet four requirements. The person must be able to understand the relevant information, retain that information, use or weigh the information as part of a decision-making process, and communicate their decision. ${ }^{37}$ There is a presumption that an adult has decision-making capacity, and to displace that presumption, it must be demonstrated they do not meet one of the four requirements. ${ }^{38}$ Under the legislation, a person is unable to make a request for VAD in advance of losing decision-making capacity by means of an advance directive. $^{39}$

The decision-making capacity assessment only requires doctors to assess whether the person meets the four requirements, not whether they consider the person's decision to be wise. ${ }^{40}$ The limited basis on which a doctor may determine a person does not have decision-making capacity is further explained in the Guidance for Health Practitioners produced by the Victorian Department of Health and Human Services. ${ }^{41}$ As that document makes clear, the presence of depression or other mental illness does not necessarily mean a person lacks decision-making capacity. What is being assessed is whether the person meets the four requirements listed and mental illness does not necessarily prevent this.

Consistent with other Victorian legislation, ${ }^{42}$ the Victorian Act also recognises decision-making capacity is decision specific, that information may be tailored to meet a person's particular needs, and that people may be supported to make decisions. The Act adopts an inclusive approach to assessing decision-making capacity, recognising that people may understand or communicate things in different ways and that this does not necessarily mean they cannot make decisions for themselves. ${ }^{43}$ The Act also recognises a person may have decision-making capacity if they are able to make a decision through the use of practicable supports. ${ }^{44}$ These provisions recognise people using non-standard forms of communication or receiving some form of support should not be excluded from accessing VAD on this basis.

\section{Disease, Illness or Medical Condition that Is Incurable}

Subsection 9(1)(d)(i) of the Victorian Act requires the relevant disease to be 'incurable'. The Explanatory Memorandum explains that this assessment is based on the individual's circumstances and comorbidities, but whether a disease is 'incurable' is a question of 'whether there is a clinically indicated treatment that

41 Department of Health and Human Services (Vic), 'Voluntary Assisted Dying: Guidance for Health Practitioners' (Clinical Guideline, 4 July 2019) $34<$ https://www2.health.vic.gov.au/hospitals-andhealth-services/patient-care/end-of-life-care/voluntary-assisted-dying/coordinating-consulting-medicalpractitioner-information $>$ ('Guidance for Health Practitioners').

42 See, eg, Medical Treatment Planning and Decisions Act 2016 (Vic) s 4; Powers of Attorney Act 2014 (Vic) s 4 .

43 Victorian Act 2017 (Vic) s 4(3).

44 Ibid s 4(4)(d). 
will cure the disease'. ${ }^{45}$ During the parliamentary debate, Minister Jennings further clarified this by stating that ' $[\mathrm{t}] \mathrm{his}$ is an objective test based on available medical treatments', ${ }^{46}$

The Explanatory Memorandum also recognises that ' $[t]$ here is a difference between managing the symptoms of a disease, illness or medical condition and curing it, which requires the complete eradication of the disease, illness or medical condition' ${ }^{47}$ For example, renal dialysis manages kidney disease, but it does not cure the disease. The fact that a person refuses treatment for a curable disease does not make it incurable (although refusing treatment may allow the condition to progress to the point that it becomes incurable). This suggests the assessment of whether a disease is incurable is a medical assessment based on available treatments and that a person will not be eligible if they are refusing treatment for an otherwise curable condition.

\section{Disease, Illness or Medical Condition that Is Advanced and Progressive}

It is not sufficient that a disease is incurable; it must also be advanced and progressive. ${ }^{48}$ These criteria mean the person's condition must be deteriorating and this deterioration must be at an advanced stage.

Neither the term 'advanced' nor the term 'progressive' is defined. The Department of Health and Human Services' Guidance for Health Practitioners suggests a condition will be progressive if 'the patient is experiencing an active deterioration'. ${ }^{49}$ Applying the ordinary meaning of the term 'advanced' suggests the condition must have significantly progressed along its expected trajectory. When applied in conjunction with the term 'progressive', it must be expected the person will continue to decline along this trajectory. This would prevent access by people in the earlier stages of a terminal condition. The extent to which a condition is advanced and progressive may also cause confusion, as both criteria are ultimately a question of degree and one may ask how far advanced a condition needs to be or what constitutes progression. In practice, the effect of these criteria and any potential confusion are likely to be limited. This is because of the further requirement that death must be expected within 6 months (or 12 months for a neurodegenerative condition). In order to meet these timeframes, it is likely the person's condition would be advanced and progressive, which gives context to what is meant by these terms.

\section{Disease, Illness or Medical Condition that Will Cause Death and Is Expected to Cause Death Within 6 or 12 Months}

The relevant condition must be one that will cause death. The necessary connection between the condition and the ultimate cause of death has not been explained in either parliamentary debates or subsequent health policies. For many

\footnotetext{
45 Explanatory Memorandum, Voluntary Assisted Dying Bill 2017 (Vic) $3 \mathrm{cl} 9$.

46 Victoria, Parliamentary Debates, Legislative Council, 21 November 2017, 6218 (Gavin Jennings).

47 Explanatory Memorandum, Voluntary Assisted Dying Bill 2017 (Vic) 3 cl 9 (emphasis added).

48 Victorian Act 2017 (Vic) s 9(d)(ii).

49 'Guidance for Health Practitioners' (n 41) 37.
} 
conditions, death may be the result of organ failure that is a predictable but not necessary outcome of the condition. For example, a metastatic cancer may hinder the functioning of the digestive system, which may result in malnourishment and dehydration that causes death. It is suggested that the requirement that a condition will cause death will be fulfilled if the condition causes a chain of events that will result in death.

Under subsection 9(1)(d)(iii) of the Victorian Act, the medical condition must be expected to cause death within 6 months, except in the case of neurodegenerative conditions where the relevant time is 12 months. The assessment of this criterion is complex because 'most prognostication tools have been developed to assist in identifying patients' needs and to plan care and support, not for determining a timescale for death'. ${ }^{50}$ The words 'expected to' in this criterion appear to recognise prognosis is not an exact science and cannot be as definitive as some of the other eligibility criteria.

While the requirement for the condition to be 'incurable' must be based on an objective assessment of clinically indicated treatments, an assessment of whether the disease will cause death and will do so within the requisite timeframe must consider the individual and the treatments acceptable to them. The Explanatory Memorandum explains that, in assessing the timeframe within which a person is expected to die, a medical practitioner must consider the 'individual's own particular circumstances, including their condition, their comorbidities, and the available treatments that they are prepared to accept, noting the right to refuse medical treatment' ${ }^{51}$ This recognises that conditions progress in different ways in different people. It also recognises that if a person has an incurable condition but there are treatments that could slow the progress of that disease, they should not be required to undergo all such treatments prior to accessing VAD. For example, a person who chooses not to undergo further chemotherapy for quality of life reasons may still be eligible for VAD even if that treatment may temporarily prolong their life.

\section{Disease, Illness or Medical Condition Is Causing Suffering}

The final criterion in subsection 9(1)(d)(iv) of the Victorian Act is that the condition must be causing suffering that cannot be relieved in a manner deemed tolerable by the person. The use of the term 'suffering' recognises that a condition may cause more than physical pain to a person, and that existential distress or other forms of suffering caused by the condition may also be sufficient. ${ }^{52}$ This assessment has two parts. First, the person's suffering must be caused by their condition. Second, the suffering must not be able to be relieved in a manner deemed tolerable by the person. Whether suffering can be relieved is a 'subjective' assessment, assessed by the person..$^{53}$

$50 \quad$ Ibid 38.

51 Explanatory Memorandum, Voluntary Assisted Dying Bill 2017 (Vic) $3 \mathrm{cl} 9$.

52 Guidance for Health Practitioners (n 41) 39.

53 Explanatory Memorandum, Voluntary Assisted Dying Bill 2017 (Vic) 3 cl 9; see also Victoria, Parliamentary Debates, Legislative Assembly, 21 September 2017, 2949 (Jill Hennessy). 


\section{Model Voluntary Assisted Dying Bill 2019}

The Model Bill was written by two of the authors and publicly released in April 2019 as a submission to the Queensland Parliament's inquiry into aged care, end of life and palliative care, and voluntary assisted dying..$^{54}$ The final report from that inquiry recommended that the Queensland government use the Bill 'as the basis for a legislative scheme for voluntary assisted dying'. ${ }^{55}$ The goal of the Model Bill was to state preferred policy positions on VAD and represent those positions in the concrete form of a draft Bill that could be considered by jurisdictions undertaking reform. Although initially submitted to a Queensland law reform exercise, the Model Bill was written not only for that State and was proposed for consideration by other Australian States too.

The Model Bill is based on a series of values that had been articulated earlier as appropriate to guide design of a VAD law. ${ }^{56}$ The values articulated as relevant were: life; autonomy; freedom of conscience; equality; rule of law; protecting the vulnerable; and reducing human suffering. In addition, influenced by the Victorian Ministerial Advisory Panel, ${ }^{57}$ added to this list was the concept of safe and high quality care..$^{58}$

The Model Bill also drew heavily on the Victorian Act, recognising that the Act had already been subject to intense scrutiny when debated and passed by an Australian Parliament. (The WA Act was not released at the time and so could not be considered.) Accordingly, the Bill adopted or adapted the drafting of the Victorian Act where the Model Bill's policy position was the same or similar. However, the application of these values did lead to some key differences between the Victorian Act and the Model Bill. ${ }^{59}$ One key difference is that the Model Bill proposes that people be given a choice between self-administration and practitioner administration, and that VAD be medically supervised. ${ }^{60}$ There are also some differences in relation to eligibility criteria.

Clause 9 of the Model Bill contains the eligibility criteria for access to VAD:

(a) the person must be aged 18 years or more; and

54 The Model Bill (n 21) was first published as a submission at $<\mathrm{https} / /$ eprints.qut.edu.au/128753/> in April 2019 and was subsequently published as Ben White and Lindy Willmott, 'A Model Voluntary Assisted Dying Bill' (2019) 7(2) Griffith Journal of Law and Human Dignity 1.

55 Queensland Parliamentary Report (n 22) 105, 'Recommendation 1'. The Model Bill (n 21) was also referred to in the Western Australian reform process: MEP Report (n 12) 78. The Model Bill is currently being considered by the Queensland Law Reform Commission as part of its role in developing proposed VAD legislation: Queensland Law Reform Commission, Queensland's Laws Relating to Voluntary Assisted Dying (Terms of Reference, 21 May 2020) <https:/www.qlrc.qld.gov.au/_data/assets/pdf_ file/0004/651379/vad-tor.pdf $>$.

56 These values are set out in Lindy Willmott and Ben White, 'Assisted Dying in Australia: A Values-based Model for Reform' in Ian Freckelton and Kerry Peterson (eds), Tensions and Traumas in Health Law (Federation Press, 2017) 479, 488-99 ('Assisted Dying in Australia').

57 MAP Report (n 25) 11, 22, 46. See also Ben P White et al, 'Does the Voluntary Assisted Dying Act 2017 (Vic) Reflect Its Stated Policy Goals?' (2020) 43(2) University of New South Wales Law Journal 417 ('Does the VAD Act (Vic) Reflect Its Stated Policy Goals?').

58 See Explanatory Notes: White and Willmott, 'Model Bill' (n 21) 6.

59 Ibid 7-14 ('Explanatory Notes').

60 Ibid $19-20 \mathrm{cl} 6$. 
(b) the person must -

(i) be an Australian citizen or permanent resident; and

(ii) be ordinarily resident in [State]; and

(c) the person must have decision-making capacity in relation to voluntary assisted dying; and

(d) the person's decision to access voluntary assisted dying must be -

(i) enduring;

(ii) made voluntarily and without coercion; and

(e) the person must be diagnosed with a medical condition that -

(i) is incurable; and

(ii) is advanced, progressive and will cause death; and

(iii) is causing intolerable and enduring suffering.

Clause 10 then clarifies certain aspects of the eligibility criteria. One clarification is that whether a person's medical condition will cause death is to be 'determined by reference to available medical treatment that is acceptable to the person'. ${ }^{61}$ This is consistent with the Victorian position above but is made explicit in the Bill. The other clarifications relate to the nature of suffering required and stipulate that suffering: ${ }^{62}$

- $\quad$ is to be subjectively determined (again consistent with the Victorian Act but explicitly stated in the Bill);

- $\quad$ includes suffering caused by treatment for the medical condition; and

- $\quad$ includes physical, psychological and existential suffering (again explicit in the Bill but consistent with the Victorian approach).

Because of the Model Bill's similarity with the Victorian Act, the focus of the discussion here will be on the ways in which the Model Bill is different on the issue of eligibility. It is anticipated that, given the intentional use of the same or similar wording as in the Victorian Act, the analysis outlined above would also be generally applicable to the Model Bill.

The most significant difference in relation to eligibility is that the Bill does not include the Victorian requirement that death is expected within a specified timeframe. It was considered that a specified time limit is arbitrary. ${ }^{63}$ Further, while a secondary consideration, not imposing a time limit avoids a registered medical practitioner having to engage in the difficult task of determining prognosis and timing of death. ${ }^{64}$ In this way, the Model Bill is wider than the Victorian Act in that it does not limit access to VAD to a window of temporal proximity to death. However, despite the absence of a time limit, the Model Bill's other requirements

61 Ibid $21 \mathrm{cl} 10(1)$.

62 Ibid $21 \mathrm{cl} \mathrm{10(2).}$

63 Ibid 8 ('Explanatory Notes'); Willmott and White, 'Assisted Dying in Australia' (n 56) 503.

64 White and Willmott, 'Model Bill' (n 21) 9 ('Explanatory Notes'); Willmott and White, 'Assisted Dying in Australia’ (n 56) 503-4. 
cumulatively operate to restrict eligibility to persons suffering with an advanced, progressive and incurable medical condition that will cause death.

The Model Bill also differs from the Victorian Act in relation to suffering. It requires 'intolerable and enduring suffering', which is arguably higher than the level of suffering required under the Victorian legislation.

Another difference relevant to the medical conditions that may be eligible for access to VAD is the definition of decision-making capacity. Clauses 7(1) and (2) of the Model Bill define capacity in terms that correspond to the Victorian definition in sections 4(1) and (2) of that Act. However, the Model Bill does not include the extended explanation of capacity contained in the Victorian Act as noted above, for example, in relation to supported decision-making. The Model Bill's requirement that VAD be medically supervised also has implications for capacity in that immediately prior to VAD being provided, whether by self-administration or practitioner administration, the registered medical practitioner must ensure the person requesting VAD still has capacity. ${ }^{65}$

There are two final differences which are noted for completeness but are unlikely to impact on whether or not a person's medical condition will satisfy the eligibility requirements. One is that the Model Bill includes, as part of its eligibility criteria, a requirement that the person's decision to access VAD is enduring and made voluntarily and without coercion. While the Victorian Act does require assessment of these factors at various points during the request and assessment process ${ }^{66}$ this is not part of its formal eligibility criteria. In practice, this may not be significant given this aspect of decision-making is assessed under both systems. The other difference is residency. Under the Model Bill, only one of Victoria's residency requirements is included: namely, being a resident of the State. There is no 12-month residency limit prior to a first request being made for VAD.

\section{Voluntary Assisted Dying Act 2019 (WA)}

Following extensive consultation over a two-year period, the Voluntary Assisted Dying Bill 2019 (WA) was introduced into the Western Australian Parliament in August 2019 and after lengthy debate was passed in December $2019 .{ }^{67}$ The WA Act broadly follows the approach of the Victorian Act. Some departures from the Victorian Act were designed to accommodate differences in the geography and demography of Western Australia. ${ }^{68}$ Other departures reflect different policy positions. One notable example is that although the WA Act retains self-administration as the default approach, in some circumstances, practitioner

65 White and Willmott, 'Model Bill' (n 21) 31-3 pt 4 div 2.

66 Victorian Act 2017 (Vic) ss 20(1)(c), 29(1)(c), 34(2)(a)(i).

67 Between August 2017-18, a Joint Select Committee inquired into end-of-life choices for Western Australians. The Committee recommended the introduction of voluntary assisted dying legislation, and in support of this recommendation the government appointed a Ministerial Expert Panel to consult and develop a legislative framework for WA. The Panel's report was tabled in Parliament on 27 June 2019: see MEP Report (n 12).

68 Western Australia, Parliamentary Debates, Legislative Assembly, 7 August 2019, 5136 (Roger Cook, Minister for Health). The most significant of these was to allow for the use of telehealth in certain circumstances. 
administration can be chosen by a person, in consultation with their medical practitioner. This can occur where the medical practitioner advises the person that self-administration would be inappropriate having regard to the person's ability to self-administer, the person's concerns about it, and the most suitable method of VAD for the patient. ${ }^{69}$

The differences between the Victorian Act and the WA Act in terms of eligibility criteria are more subtle. Subsection 16(1) of the WA Act contains the eligibility criteria that must be met for access to VAD:

a) the person has reached 18 years of age;

b) the person-

(i) is an Australian citizen or permanent resident; and

(ii) at the time of making a first request, has been ordinarily resident in Western Australia for a period of at least 12 months;

c) the person is diagnosed with at least 1 disease, illness or medical condition that -

(i) is advanced, progressive and will cause death; and

(ii) will, on the balance of probabilities, cause death within a period of 6 months or, in the case of a disease, illness or medical condition that is neurodegenerative, within a period of 12 months; and

(iii) is causing suffering to the person that cannot be relieved in a manner that the person considers tolerable;

d) the person has decision-making capacity in relation to voluntary assisted dying;

e) the person is acting voluntarily and without coercion; and

f) the person's request for access to voluntary assisted dying is enduring.

As in Victoria, the WA Act states that disability and mental illness alone are not grounds to access VAD ${ }^{70}$ However, also like in Victoria, extrinsic material confirms that provided the eligibility criteria are met, the presence of a disability or a mental illness in itself will not preclude a person from accessing VAD. ${ }^{71}$

Because the eligibility criteria in the WA Act are so similar to those in the Victorian Act, the remaining discussion will focus on key areas of difference, and where appropriate, comparisons with the Model Bill. ${ }^{72}$ A key difference between the WA Act and both the Victorian Act and Model Bill is that in Western Australia there is no requirement for an eligible condition to be 'incurable'. In Victoria, whether or not a disease, illness or condition is incurable is viewed as an objective test based on available medical treatments. ${ }^{73}$ This explanation was provided in the context of

69 Voluntary Assisted Dying Act 2019 (WA) s 56(2) ('WA Act’).

70 Ibid s 16(2).

71 Explanatory Memorandum, Voluntary Assisted Dying Bill 2019 (WA) 6 cl 15.

72 One minor difference noted but not considered further is that the WA Act, like the Victorian Act, requires a person to be ordinarily resident in the State for at least 12 months before the first request for VAD, but it does not repeat the (superfluous) requirement in the Victorian Act to also be ordinarily resident in the State: WA Act 2019 (WA) s 16(1)(b); Victorian Act 2017 (Vic) s 9(1)(b).

73 Victoria, Parliamentary Debates, Legislative Council, 21 November 2017, 6218 (Gavin Jennings). 
discussion about the ability of medical practitioners to accurately prognosticate about how long a person may have to live. ${ }^{74}$ The presence of an incurable illness that was advanced and progressive would strongly indicate that the end of life was near. In considering a legislative framework for Western Australia, the Ministerial Expert Panel ('MEP') did not specifically engage with the concept of an incurable disease ${ }^{75}$ but instead explored whether a person should have a 'terminal' condition in order to be eligible to access VAD ${ }^{76}$ They formed the view that including a criterion that an illness or disease is 'advanced, progressive and will cause death' clearly 'emphasise[s] the terminal nature of the illness or disease'. ${ }^{77}$ Consequently, further qualification of the type of illness, disease or condition was not seen as being required, and the WA Act does not refer to an 'incurable' condition. In debate on the Bill, the government indicated that they considered the term 'incurable' just reiterated existing criteria. ${ }^{78}$ The Premier, Mark McGowan also observed that including a criterion of 'incurable' might require a person to undergo treatment they wish to refuse, or exhaust all treatment options, ${ }^{79}$ potentially including experimental treatment in 'some far-flung place around the world' ${ }^{80}$ This would 'cut across the fundamental principle of patient autonomy' ${ }^{81}$

In contrast, providing a timeframe within which a person is expected to die was seen as an important safeguard in the legislative framework. ${ }^{82}$ The Model Bill does not require medical practitioners to engage with the challenging problem of estimating when a person might die, in part, because any suggested timeframe would be arbitrary. While substantially reflecting the Victorian Act, the WA Act seeks to address the prognostic challenge of estimating when a person might die by requiring the assessment of life expectancy on the balance of probabilities. ${ }^{83}$ That is, a medical practitioner must be satisfied that it is more likely than not ${ }^{84}$ that the person will die within 6 months (or 12 months in the case of a person with a neurodegenerative condition) ${ }^{85}$ In determining if a disease, illness or condition is likely to cause the death of a person, the medical practitioner can take account of the person's individual circumstances, their comorbidities and their treatment

74 Ibid.

75 Although the MEP did refer to the fact that Canada's and Luxembourg's laws require an incurable condition: MEP Report (n 12) 33.

76 Ibid 33-4.

77 Ibid 34.

78 Western Australia, Parliamentary Debates, Legislative Council, 26 November 2019, 9200 (Stephen Dawson). See also Western Australia, Parliamentary Debates, Legislative Assembly, 5 September 2019, 6586 (Mark McGowan).

79 Western Australia, Parliamentary Debates, Legislative Assembly, 5 September 2019, 6586 (Mark McGowan). See also Western Australia, Parliamentary Debates, Legislative Council, 26 November 2019, 9200 (Stephen Dawson).

80 Western Australia, Parliamentary Debates, Legislative Council, 26 November 2019, 9200 (Stephen Dawson).

81 Western Australia, Parliamentary Debates, Legislative Assembly, 5 September 2019, 6603 (Roger Cook).

82 MEP Report (n 12) 36-40.

83 WA Act 2019 (WA) s 16(1)(c)(ii).

84 See generally John Dyson Heydon, Cross on Evidence (LexisNexis Butterworths, $12^{\text {th }}$ ed, 2020) 387-9.

85 WA Act 2019 (WA) s 16(1)(c)(ii). 
choices ${ }^{86}$ making it more than a pure mathematical exercise in probabilities. Traditionally, the 'balance of probabilities' has been reserved for tribunals trying to determine particular facts from competing or contradictory claims. ${ }^{87}$ Parliamentary debate sheds little light on this terminology, other than to observe that 'the test is easily understood and has case law to support it ${ }^{9}{ }^{88}$ and is commonly used and well understood by medical practitioners. ${ }^{89}$ The MEP originally recommended the use of the phrase 'reasonably foreseeable', and did not mention 'balance of probabilities' ${ }^{90}$ However, legal officers within the government felt that 'reasonably foreseeable' was not clear enough, and that 'balance of probabilities' provided the 'greatest clarity' and 'most utility'. ${ }^{11}$ How it does so, and how or if it differs from 'expected' or 'reasonably foreseeable', was not explained. It was confirmed, however, in parliamentary debates that this new wording was not intended to import a lower standard than is contained in the Victorian Act. ${ }^{92}$

The WA Act, like the Victorian Act and the Model Bill, requires a person seeking access to VAD to have decision-making capacity in relation to VAD and requires capacity to be assessed at several points throughout the process. Like Victoria, the final assessment of capacity occurs at the point of practitioner administration, or for self-administration, at the conclusion of the request and assessment process (but not at the time of later ingestion). The WA Act, however, defines decisionmaking capacity in slightly different terms from the Victorian Act,${ }^{93}$ presumably to promote consistency with other Western Australian legislation defining decisionmaking capacity. ${ }^{94}$ However, the similarity in approach means that its effect is likely to be the same. The WA Act, like the Model Bill, also does not have the extended explanation of capacity found in the Victorian Act.

For completeness, it is noted that the WA Act mirrors the Model Bill in including a requirement that the person's decision to access VAD must be enduring, made voluntarily and without coercion as part of the eligibility criteria..$^{95}$ Although different from the Victorian Act, as suggested above, the practical effect of this difference is likely to be insignificant.

86 Explanatory Memorandum, Voluntary Assisted Dying Bill 2019 (WA) 5 cl 15.

87 James Allsop et al, 'Are You Sure?' (2019) 47(2) Australian Bar Review 122, 124.

88 Western Australia, Parliamentary Debates, Legislative Assembly, 5 September 2019, 6582 (Mark McGowan), 6606 (Roger Cook).

89 Western Australia, Parliamentary Debates, Legislative Assembly, 5 September 2019, 6606 (Roger Cook); Western Australia, Parliamentary Debates, Legislative Council, 26 November 2019, 9196 (Stephen Dawson).

90 MEP Report (n 12) 36-9.

91 Western Australia, Parliamentary Debates, Legislative Assembly, 5 September 2019, 6606-7 (Roger Cook); Western Australia, Parliamentary Debates, Legislative Council, 26 November 2019, 9196 (Stephen Dawson).

92 Western Australia, Parliamentary Debates, Legislative Council, 26 November 2019, 9196 (Stephen Dawson).

93 WA Act 2019 (WA) s 6.

94 See, eg, Mental Health Act 2014 (WA) s 15.

95 WA Act 2019 (WA) ss 16(1)(e), (f). 


\section{E Death with Dignity Act (Oregon)}

The Oregon $A c t^{96}$ was passed through a ballot initiative process. At the November 1994 election, Oregon's citizens voted directly to approve the law by 51 to 49 percent. ${ }^{97}$ However, a series of constitutional challenges delayed the implementation of the law by three years ${ }^{98}$ until the injunction against the operation of the law was lifted on 27 October 1997. ${ }^{99}$ In November 1997, Oregonians rejected a direct ballot designed to repeal the Oregon Act, by a margin of 60 to 40 percent. ${ }^{100}$ The law has been operational since that time. ${ }^{101}$

The Oregon Act, on which legislation in other US states is based, ${ }^{102}$ has a rigorous assessment process that has been described as 'so carefully crafted, so narrowly drawn, and so laden with procedural safeguards that it may well demand more energy and fortitude to comply with it than some terminally ill people are likely to have' ${ }^{103}$ The model of VAD in Oregon is restricted to a doctor prescribing medication which the patient self-administers. There is no provision for practitioner administration.

The Oregon Act provides that to be eligible to request assistance to die a person must be: ${ }^{104}$

An adult who is capable, is a resident of Oregon, and has been determined by the attending physician and consulting physician to be suffering from a terminal disease, and who has voluntarily expressed his or her wish to die ...

96 Oregon Act, Or Rev Stat $\S 127.800-127.995$ (1994).

97 Patrick M Curran Jr, 'Regulating Death: Oregon's Death with Dignity Act and the Legalization of Physician-Assisted Suicide' (1998) 86(3) Georgetown Law Journal 725, 728.

98 It was argued that the legislation violated a number of constitutional rights, including due process and equal protection rights under the Fourteenth Amendment; the free exercise of religion and freedom of association rights under the First Amendment; and statutory rights under the Americans with Disabilities Act of 1990, 42 USC §§ 12101-213; section 504 of the Rehabilitation Act of 1973, 29 USC §§ 701-961; and the Religious Freedom Restoration Act of 1993, 42 USC $\S \S 2000 \mathrm{bb}-\mathrm{bb} 4$. The District Court of Oregon found the Act violated the equal protection clause, and issued injunctions preventing the law commencing: Lee v Oregon, 869 F Supp 1491 (D Or, 1994) (issuing preliminary injunction); Lee v Oregon, 891 F Supp 1429 (D Or, 1995) (equal protection opinion); Lee v Oregon, 891 F Supp 1439 (D Or, 1995) (issuing permanent injunction). On appeal, the Ninth Circuit Court held that the plaintiffs lacked standing: Lee v Oregon, 107 F 3d 1382 (9 ${ }^{\text {th }}$ Cir, 1997), and the Supreme Court refused leave to appeal: Lee v Harcleroad, 522 US 927 (1997). For discussion of these cases, see Brian Boyle, 'The Oregon Death with Dignity Act: A Successful Model or a Legal Anomaly Vulnerable to Attack' (2004) 40(5) Houston Law Review 1387, 1393-5.

99 Curran (n 97) 729; Boyle (n 98) 1391.

100 Curran (n 97) 729; Raphael Cohen-Almagor and Monica G Hartman, 'The Oregon Death with Dignity Act: Review and Proposals for Improvement' (2001) 27(2) Journal of Legislation 269, 274.

101 The law has been subject to, and survived, later litigation not directly challenging the statute itself, but alleging that a medical practitioner who prescribed drugs for assisted dying was not prescribing for a 'legitimate medical purpose' within the meaning of the federal Controlled Substances Act, 21 USC $\S \S$ 821-32, and consequently risked having his or her registration revoked: Oregon v Ashcroft, 192 F Supp 2d 1077 (D Or, 2002); Oregon v Ashcroft, 368 F 3d 1118 (9 ${ }^{\text {th }}$ Cir, 2004); Gonzales v Oregon, 546 US 243 (2006). For discussion of these cases, see Boyle (n 98) 1396-9.

102 See above $\mathrm{n} 6$ for the legislation in other US states.

103 Alan Meisel, Kathy L Cerminara and Thaddeus M Pope, The Right to Die: The Law of End-of-Life Decisionmaking (Wolters Kluwer, $3^{\text {rd }}$ ed, 2016) 12-91 §12.06[A][1].

104 Oregon Act, Or Rev Stat $§ 127.805(1)$ (1994). 
Age or disability is specifically noted as being insufficient, of itself, to qualify for assistance to die. ${ }^{105}$ Each of the Act's eligibility criteria, aside from being an adult and residence, will be considered separately below.

\section{Capacity}

To make a request for VAD a person must be 'capable', which is defined as having 'the ability to make and communicate health care decisions to health care providers' ${ }^{106}$ Communication can be made through persons familiar with the patient's manner of communicating if necessary. Capacity must be assessed by the patient's attending physician and consulting physician in every case before VAD is authorised, ${ }^{107}$ and may additionally be evaluated by a psychiatrist or psychologist if there is concern that the person might be 'suffering from a psychiatric or psychological disorder or depression causing impaired judgment' ${ }^{108}$ The Oregon Act does not allow a person to request VAD in an advance directive. ${ }^{109}$ While the person must have decision-making capacity at the time of the request and assessment process, capacity does not need to be assessed again at the point a person ingests the medication. ${ }^{110}$

\section{Terminal Disease}

A person must be 'suffering from a terminal disease' 111 to be eligible to receive assistance to die in Oregon. 'Terminal disease' is defined to mean 'an incurable and irreversible disease that has been medically confirmed and will, within reasonable medical judgment, produce death within six months'. ${ }^{112}$ This means that a person with a chronic illness, such as Parkinson's disease or multiple sclerosis, which is incurable but will not of itself result in death, is not eligible under the legislation. ${ }^{113}$

'Medically confirmed' means that the diagnosis of a terminal disease is determined by two doctors: the attending physician and the consulting physician. The 'attending physician' is the doctor who has primary responsibility for the care of the patient and treatment of the terminal disease. ${ }^{114}$ The attending physician

105 Ibid § 127.805(2).

106 Ibid $\S 127.800(3)$.

107 Ibid $\S \S 127.815(1)(a), 127.820$.

108 Ibid $\$ 127.825$. These words were added by amendments in 1999: Meisel, Cerminara and Pope (n 103) $12-92.4 \S 12.06[\mathrm{~A}][1]$. The Act specifically prohibits access to VAD for this cohort being evaluated until it is determined that 'the patient is not suffering from a psychiatric or psychological disorder or depression causing impaired judgment': Oregon Act, Or Rev Stat § 127.825 (1994). As to the role of depression in impairing decision-making, see Linda Ganzini, 'Legalised Physician-Assisted Death in Oregon' (2016) 16(1) QUT Law Review 76, 81-3.

109 See Ganzini (n 108) 77.

110 Note that Ganzini (n 108) raises concern about the possibility that a person may have lost capacity by that stage: at 81 .

111 Oregon Act, Or Rev Stat § 127.805(1) (1994).

112 Ibid $\S 127.800(12)$.

113 This distinction is made by IG Finlay and R George, 'Legal Physician-Assisted Suicide in Oregon and The Netherlands: Evidence Concerning the Impact on Patients in Vulnerable Groups' (2011) 37(3)

Journal of Medical Ethics 171, 173.

114 Oregon Act, Or Rev Stat § 127.800(2) (1994). 
makes the initial diagnosis that the disease is terminal. This medical opinion is then confirmed by a consulting physician, after examining the patient and the patient's relevant medical records. ${ }^{115}$

Neither 'incurable' nor 'irreversible' is defined, so it is unclear whether the statute would include a person who refused available medical treatment which has a chance of curing or reversing the process of disease, thus rendering an otherwise non-fatal condition terminal. ${ }^{116}$ Oregon's Guidebook for Health Care Professionals suggests that '[d]oubts concerning the patient's diagnosis, prognosis, and volition should be resolved against provision of medication'. ${ }^{117}$ That is, where the doctor is uncertain whether or not the patient qualifies as terminally ill, they should refuse a request for VAD. However, this guidance does not directly address the issue of treatment refusal. In practice, the application of 'incurable and irreversible' may vary according to the condition from which the person is suffering. For example, an Oregon doctor stated that he declined a request for VAD from a diabetic patient who was refusing insulin treatment, but he would accept a request from a person with treatable lymphoma who was refusing chemotherapy. ${ }^{118}$ The application of the statutory criteria may also vary according to the views of the assessing doctor, as other doctors have stated they would not accept a request from a person refusing lymphoma treatment. ${ }^{119}$

\section{Suffering}

There is no separate requirement under the Oregon Act that a person be in pain, or experiencing any suffering. ${ }^{120}$ In this sense, the phrase 'suffering from a terminal illness' means having or experiencing such an illness.

\section{Voluntary}

To be eligible for VAD, a person must have 'voluntarily expressed his or her wish to die'. ${ }^{121}$ The criteria for voluntariness are not defined in the Oregon Act, or in rules or regulations made under the Act. ${ }^{122}$ However, witnesses are required to

115 Ibid $\S 127.800(8)$.

116 The Oregon Health Authority (unhelpfully) states that: 'The Act does not specify whether or not all treatment options must be exhausted prior to a prescription being written': Oregon Health Authority, 'Public Health's Role: Oregon's Death with Dignity Act', (Web Page) <https://www.oregon.gov/oha/PH/ PROVIDERPARTNERRESOURCES/EVALUATIONRESEARCH/DEATHWITHDIGNITYACT/Pages/ ohdrole.asp $x>$.

117 Kelly Hagan, 'Liability and Negligence' in Patrick Dunn and Bonnie Reagan (eds), The Oregon Death with Dignity Act: A Guidebook for Health Care Professionals, (Centre for Ethics in Health Care, Oregon Health and Science University, 2007) ch 15, Guideline $15.10<\mathrm{https} / /$ www.wsha.org/wp-content/uploads/ Death-with-Dignity_Death-with-dignity-guidebook.pdf>.

118 Anita Hannig, 'Author(iz)ing Death: Medical Aid-in-Dying and the Morality of Suicide' (2019) 34(1) Cultural Anthropology 53, 70 .

119 Ibid.

120 See Herbert Hendin and Kathleen Foley, 'Physician-Assisted Suicide in Oregon: A Medical Perspective' (2008) 106(8) Michigan Law Review 1613, 1615.

121 Oregon Act, Or Rev Stat § 127.805(1) (1994).

122 James L Werth Jr and Howard Wineberg, 'A Critical Analysis of Criticisms of the Oregon Death With Dignity Act' (2004) 29(1) Death Studies 1, 20; Michaela Estelle Okninski, 'Commentary on Undue 
sign, as part of a person's request for assisted dying, that the person 'appears to be ... not under duress, fraud or undue influence'. ${ }^{123}$ It has been suggested that acting voluntarily involves excluding external influences such as duress, fraud or undue influence. ${ }^{124}$

\section{F Canadian Criminal Code}

In February 2015, in Carter v Canada (Attorney General) ('Carter'), ${ }^{125}$ the Supreme Court of Canada struck down the Criminal Code prohibition on voluntary euthanasia and assisted suicide, ruling it was contrary to the Canadian Charter of Rights and Freedoms ('Charter'):

The appropriate remedy is therefore a declaration that s. $241(b)$ and s. 14 of the Criminal Code are void insofar as they prohibit physician-assisted death for a competent adult person who (1) clearly consents to the termination of life; and (2) has a grievous and irremediable medical condition (including an illness, disease or disability) that causes enduring suffering that is intolerable to the individual in the circumstances of his or her condition. 'Irremediable', it should be added, does not require the patient to undertake treatments that are not acceptable to the individual. ${ }^{126}$

In response to this decision, albeit after 16 months, ${ }^{127}$ the Canadian Parliament passed An Act to Amend the Criminal Code and to Make Related Amendments to Other Acts (Medical Assistance in Dying) in June 2016 ('Bill C-14'). ${ }^{128}$ This legislation permits 'medical assistance in dying' (MAiD), after a person seeking

Influence Provisions under Oregon's Death with Dignity Act and California's End of Life Option Act' (2017) 25(1) Journal of Law and Medicine 77, 80. Clinical criteria to assess voluntariness have been proposed in David Orentlicher, Thaddeus Mason Pope and Ben A Rich, 'Clinical Criteria for Physician Aid in Dying' (2016) 19(3) Journal of Palliative Medicine 259.

123 Oregon Act, Or Rev Stat § 127.897 (1994).

124 For this interpretation, see Okninski (n 122) 80. A witness' ability to attest to voluntariness has been questioned by Hendin, Foley and White who note that there is no requirement that the witnesses be independent of the person, or even that they know the person: Herbert Hendin, Kathleen Foley and Margot White, 'Physician-Assisted Suicide: Reflections on Oregon's First Case' (1998) 14(3) Issues in Law and Medicine 243, 254-5. Note also that Okninski has suggested that the Oregon Act does not provide sufficient protection against external factors which may overbear a person's will, because doctors are not required to report refusals of requests on the ground of concerns about voluntariness. This allows doctor shopping until a person or their relative finds a doctor willing to certify that a request for assistance to die is voluntary. Okninski cited anecdotal evidence of the Kate Cheney case, in which two doctors and a psychiatrist refused Ms Cheney's request because of concerns of undue influence or coercion by her daughter, before a doctor was found who was willing to write a prescription for lethal medication: Okninski (n 122) 82-3, citing Kathleen Foley and Herbert Hendin, 'Physician-Assisted Suicide in Oregon: A Medical Perspective' (2008) 24(2) Issues in Law and Medicine 121, 131-2. We note, however, that the source of information about Kate Cheney for the Foley and Hendin paper is a 1999 newspaper article.

125 Carter v Canada (Attorney General) [2015] 1 SCR 331 ('Carter'). For commentary on this case, see Jocelyn Downie, 'Permitting Voluntary Euthanasia and Assisted Suicide: Law Reform Pathways for Common Law Jurisdictions' (2016) 16(1) QUT Law Review 84, 96-8.

126 Carter [2015] 1 SCR 331, 390 [127] (emphasis in original).

127 The Court suspended the declaration of invalidity for 12 months to allow the Canadian government to develop a legislative response to the judgment: Carter [2015] 1 SCR 331, 396 [147]. The suspension was then extended by a further four months due to a period of legislative inactivity because of an election: Carter v Canada (Attorney General) [2016] 1 SCR 13.

128 Bill C-14, $1^{\text {st }}$ Sess, $42^{\text {nd }}$ Parl, 2016, amending the Canadian Criminal Code, RSC 1985, c C-46, ss 14, 226, 241. Although note that provincial legislation permitting VAD was first enacted in Quebec which commenced operation in December 2015: Act Respecting End-of-Life Care, RSQ c S-32.0001. 
access for this assistance has been found to be eligible through a rigorous assessment process. MAiD includes both practitioner administration and self-administration, although, to date, self-administration has been very rarely used. ${ }^{129}$

For a person to be eligible for MAiD, Bill C-14 required that:

241.2(1)

(a) they are eligible - or, but for any applicable minimum period of residence or waiting period, would be eligible - for health services funded by a government in Canada;

(b) they are at least 18 years of age and capable of making decisions with respect to their health;

(c) they have a grievous and irremediable medical condition;

(d) they have made a voluntary request for medical assistance in dying that, in particular, was not made as a result of external pressure; and

(e) they give informed consent to receive medical assistance in dying after having been informed of the means that are available to relieve their suffering, including palliative care.

if:

Bill C-14 stated that a person has a grievous and irremediable medical condition

(a) they have a serious and incurable illness, disease or disability;

(b) they are in an advanced state of irreversible decline in capability;

(c) that illness, disease or disability or that state of decline causes them enduring physical or psychological suffering that is intolerable to them and that cannot be relieved under conditions that they consider acceptable; and

(d) their natural death has become reasonably foreseeable, taking into account all of their medical circumstances, without a prognosis necessarily having been made as to the specific length of time that they have remaining. ${ }^{30}$

Aspects of Bill C-14 were controversial from the outset, in particular the requirement that to amount to a grievous and irremediable medical condition a person's natural death must be 'reasonably foreseeable'. ${ }^{131}$ Critics argued that this criterion violated the Charter, was too uncertain and was not an accurate reflection of the Supreme Court's reasoning in Carter. ${ }^{132}$ On 11 September 2019, in

129 Christopher Harty et al, 'Oral Medical Assistance in Dying (MAiD): Informing Practice to Enhance Utilization in Canada' (2019) 66(9) Canadian Journal of Anaesthesia 1106.

$130{\text { Bill C-14, } 1^{\text {st }} \text { Sess, 42 }}^{\text {nd }}$ Parl, 2016, s 3, inserting Canadian Criminal Code, RSC 1985, c C-46, s 241.2(2).

131 'Reasonably foreseeable' is not defined in the legislation. It is widely accepted that 'reasonably foreseeable' is not limited to situations in which: death is solely caused by the grievous and irremediable condition; death is imminent; the patient has a fatal condition; the patient is terminally ill; or the patient has an expected remaining lifespan of six months (as in Oregon, for example). See $A B v$ Canada (Attorney General) (2017) 138 OR (3d) 139; Jocelyn Downie and Jennifer A Chandler, Interpreting Canada's Medical Assistance in Dying Legislation (IRPP Report, 1 March 2018) < https://irpp.org/ research-studies/interpreting-canadas-medical-assistance-in-dying-maid-legislation> ('IRPP Report').

132 See, eg, Jocelyn Downie and Kate Scallion, 'Foreseeably Unclear: The Meaning of the 'Reasonably Foreseeable' Criterion for Access to Medical Assistance in Dying in Canada' (2018) 41(1) Dalhousie Law Journal 23; James Downar and Louise Hugo Francescutti, 'Medical Assistance in Dying: Time for Physicians to Step up to Protect Themselves and Patients' (2017) 189(25) Canadian Medical Association Journal E849. The primary source of uncertainty over 'reasonably foreseeable' death is how close to death 
Truchon v Procureur Général du Canada ('Truchon'), ${ }^{133}$ Baudouin J of the Quebec Superior Court accepted aspects of these arguments, and ruled that the 'reasonably foreseeable' eligibility criterion was constitutionally invalid. ${ }^{134}$ In response to the Truchon decision, on 17 March 2021, An Act to Amend the Criminal Code (Medical Assistance in Dying) ('Bill C-7') was passed and came into force. ${ }^{135}$ Bill C-7 makes three changes to the law that are of particular relevance to this article:

1. It repeals the eligibility criterion in section 241.2(2)(d) that a person's natural death must be reasonably foreseeable; ${ }^{136}$

2. It explicitly stipulates that (until 17 March 2023) for the purposes of determining whether someone has a serious and incurable illness, disease, or disability, mental illness is not considered an illness, disease, or disability; ${ }^{137}$ and

3. It permits two forms of requests for MAiD made in advance of loss of decision-making capacity (a 'final consent waiver' and 'advance consent' explained in detail below). ${ }^{138}$

\section{Decision-Making Capacity}

The first eligibility criterion, in section 214.2(1)(a) of the Canadian Criminal Code, which we will not consider in detail, is that a person must be eligible for health services in Canada. The second criterion, in section 241.2(1)(b), is that a person accessing MAiD must be capable of making decisions with respect to their health. Two independent health practitioners must be of the opinion that this criterion and the other eligibility requirements are satisfied. ${ }^{139}$ The capacity

a person must be to satisfy this requirement. On a narrow interpretation, a temporal link to death is required and that period of time must not be too remote, even though the medical or nurse practitioner does not have to estimate a specific length of time. On a broader interpretation, this criterion would be satisfied if either death is predicted in a period of time that is not too remote or there is a predictable cause of death. This latter interpretation is supported by, for example, College of Physicians and Surgeons of Nova Scotia, 'Professional Standard Regarding Medical Assistance in Dying' (Professional Standard, 14 December 2018) <https://cpsns.ns.ca/wp-content/uploads/2018/12/ProfessionalStandard_MedicalAssistanceInDying Dec2018.pdf>. In contrast, when introducing Bill C-7 Justice Minister David Lametti appeared to endorse a narrower standard, although his office later clarified via email that the definition had not changed: Joan Bryden, 'Lametti Sows Uncertainty over Meaning of Foreseeable Death in Assisted-Dying Bill', National Newswatch (online, 3 March 2020) <https://www.nationalnewswatch.com/2020/03/03/lametti-sowsuncertainty-over-meaning-of-foreseeable-death-in-assisted-dying-bill-2/\#.X18BMkBuLvV>.

133 (2019) 158 WCB (2d) 246.

134 Baudouin J suspended her declaration of invalidity for six months, giving the government until 11 March 2020 to amend the legislation (should it wish to do so). The government obtained four extensions of this deadline and had until 26 March 2021 to pass Bill C-7. See Joan Bryden 'Feds Get Another Month to Reform Assisted-Dying Law as Bill Stalls in the Commons' CBC News (online, 25 February 2021) $<$ https://www.cbc.ca/news/politics/assisted-death-maid-1.5928316>; Truchon v Procureur Général du Canada (2021) 171 WCB (2d) 65.

135 Bill C-7, $1^{\text {st }}$ Sess, $43^{\text {rd }}$ Parl, 2020 came into force on 17 March $2021<$ https://parl.ca/DocumentViewer/ en/43-2/bill/C-7/royal-assent>.

136 Ibid s 1(1), repealing Canadian Criminal Code, RSC 1985, c C-46, s 241.2(2)(d).

137 Bill C-7, $1^{\text {st }}$ Sess, 43rd Parl, 2020, s 1(2), inserting Canadian Criminal Code, RSC 1985, c C-46, s 241.2(2.1).

138 Bill C-7, $1^{\text {st }}$ Sess, 43 ${ }^{\text {rd }}$ Parl, 2020, s 1(7), inserting Canadian Criminal Code, RSC 1985, c C-46, ss 241.2(3.2) ('final consent - waiver'), (3.5) ('advance consent - self-administration').

139 Canadian Criminal Code, RSC 1985, c C-46, ss 241.2(3)(a), (e), (f). 
requirement is phrased more broadly in the Canadian Criminal Code than in the Australian models, which state that the person must have decision-making capacity for VAD specifically. In practice, however, capacity assessments are similar in Canada because it is understood that capacity in the health care context (and MAiD is understood to be a form of health care) is decision specific.

The test for capacity is framed somewhat differently depending on the Canadian province or territory, but all provincial/territorial statutes centre on understanding the proposed treatment and appreciating the consequences of the decision. ${ }^{140}$ Several provinces state that a person is capable of making a treatment decision if they: 1) understand the information that is relevant to making the decision; and 2) appreciate the reasonably foreseeable consequences of both choosing the treatment and not choosing the treatment. ${ }^{141}$ Other jurisdictions adopt additional, ${ }^{142}$ or slightly different criteria. ${ }^{143}$

Canada is unique amongst the jurisdictions considered in this article in permitting two limited forms of advance request for MAiD, through the 'final consent waiver' and 'advance consent - self-administration'. The default position in Canada is that a person must have capacity when making the request for MAiD and later when giving express consent immediately before it is provided. ${ }^{144}$ However, this latter requirement can be waived for persons in two circumstances. First, for individuals whose natural death is reasonably foreseeable who have lost capacity after they have been found eligible for MAiD ('final consent waiver'). ${ }^{145}$ The final consent waiver is only valid if the person satisfies all eligibility criteria and safeguards in the legislation, and they have entered into a written agreement with a doctor or nurse practitioner to provide MAiD on a specified day. ${ }^{146}$ The doctor or nurse practitioner must also have informed the person about the risk of losing capacity prior to the day specified. ${ }^{147}$ If the person loses capacity, MAiD can be provided on or before the specified day. Despite this final consent waiver, the doctor or nurse practitioner must not administer the substance if the person resists or refuses by words, sounds or gestures. ${ }^{148}$ Second, for persons (whether natural

140 See, eg, Adult Guardianship and Trusteeship Act, SA 2008, c A-4.2, s 1(d); Health Care (Consent) and Care Facility (Admission) Act, RSBC 1996, c 181, s 7; Health Care Directives and Substitute Health Care Decision Makers Act, SS 2015, c H-0.002, s 2(1); Health Care Directives Act, CCSM 1993, c H27, s 2; Health Care Consent Act, SO 1996, c 2, sch A s 4.

141 Adult Guardianship and Trusteeship Act, SA 2008, c A-4.2, s 1(d); Health Care Directives Act, CCSM 1993, c H27, s 2; Health Care Consent Act, SO 1996, c 2, sch A s 4.

142 The Saskatchewan legislation adopts the two criteria used in Ontario, Alberta and Manitoba, and also requires that a person must be able to communicate a decision about the proposed treatment: Health Care Directives and Substitute Health Care Decision Makers Act, SS 2015, c H-0.002, s 2(1).

143 In British Columbia, the Health Care (Consent) and Care Facility (Admission) Act, RSBC 1996, c $181, \mathrm{~s} 7$ requires the health care provider to assess whether the adult demonstrates that they understand information about the proposed treatment.

144 Canadian Criminal Code, RSC 1985, c C-46, ss 241.2(1)(b), (e), (3)(a), (h), (3.1)(a), (k).

145 Ibid s 241.2(3.2).

146 Ibid s 241.2(3.2)(a)(i), (ii).

147 Ibid s 241.2(3.2)(a)(iii).

148 Ibid s 241.2(3.2)(c). Note also that section 241.2(3.3) clarifies that 'involuntary words, sounds or gestures made in response to contact do not constitute a demonstration of refusal or resistance for the purposes of paragraph $(3.2)(\mathrm{c})$ '. 
death is reasonably foreseeable or not) who enter into a written arrangement with their provider for MAiD to be provided should self-administration fail. In such circumstances, if the person has lost capacity, the practitioner was present at the time of self-administration, and the person has not died within the specified period, the provider-administered MAiD is permitted. ${ }^{149}$

\section{Grievous and Irremediable Medical Condition}

The most complex aspect of the eligibility criteria for MAiD is the requirement that the person have a grievous and irremediable medical condition. Section 241.2(2) of the Canadian Criminal Code states that a person will have a grievous and irremediable medical condition if: ${ }^{150}$

(a) they have a serious and incurable illness, disease or disability;

(b) they are in an advanced state of irreversible decline in capability; and

(c) that illness, disease or disability or that state of decline causes them enduring physical or psychological suffering that is intolerable to them and that cannot be relieved under conditions that they consider acceptable.

\section{(a) Serious and Incurable Illness, Disease or Disability}

The first requirement for a 'grievous and irremediable medical condition' is that the person must have a serious and incurable illness, disease or disability. ${ }^{151}$ A key issue is whether the medical condition must be incurable by any means, or whether it is limited to means that are acceptable to the patient. ${ }^{152}$ Parliament did not define 'incurable' in the Canadian Criminal Code, nor did the government define it in its glossary to Bill C-14, and there is no case law on point. One interpretation is that 'incurable' should be viewed from an objective perspective because the government did not reference treatments acceptable to the person in the legislation,

149 Ibid s 241.2(3.5).

150 Ibid s 241.2(2).

151 Ibid s 241.2(2)(a).

152 Note that this aspect of the Canadian Criminal Code is one of the grounds for a 2016 constitutional challenge launched by Julia Lamb and the British Columbia Civil Liberties Association shortly after Bill C-14 was passed ('Lamb'). For background on the case see the interim ruling: Lamb and British Columbia Civil Liberties Association v Canada (Attorney General) (2017) 5 BCLR (6 $\left.6^{\text {th }}\right) 175$. See also Julia Lamb and British Columbia Civil Liberties Association, 'Notice of Civil Claim', Notice of Civil Claim in Lamb and British Columbia Civil Liberties Association v Canada (Attorney General), Supreme Court of British Columbia, No S-165851, 27 June $2016<$ http://eol.law.dal.ca/wp-content/ uploads/2016/07/Lamb-v-Canada.pdf> ('Lamb Claim'). This litigation is now adjourned indefinitely. Lamb and the British Columbia Civil Liberties Association argued, in part, that the legislation is overbroad and violates the Canada Act 1982 (UK) c 11, sch B pt I ('Charter') for those individuals who have a grievous and irremediable medical condition that is curable, but only by treatment options unacceptable to the patient. Note that the Attorney General in its Response to Civil Claim argued that the law does not infringe the Charter (or alternatively, if it does is a reasonable limit under section 1), but does not directly address the issue of treatments that are acceptable to the person: 'Response to Civil Claim', Response to Civil Claim in Lamb and British Columbia Civil Liberties Association v Canada (Attorney General), Supreme Court of British Columbia, No S-165851, 27 July $2016<$ https://bccla.org/ wp-content/uploads/2016/08/2016-07-27-Response-to-Civil-Claim.pdf>. 
as it did in relation to the criterion of suffering. ${ }^{153}$ The other interpretation, now widely accepted by MAiD assessors and providers' lawyers based on Carter, and statements made in Parliament, is that incurable should be interpreted by reference to treatment that is acceptable to the person..$^{154}$

Section 241.2(2.1) of the Canadian Criminal Code stipulates that a mental illness is not considered to be an illness, disease or disability under section 241.2(2) (a). This exclusion will be automatically repealed on 17 March 2023 by operation of a 'sunset clause' included in Bill C-7. ${ }^{155}$

\section{(b) Advanced State of Irreversible Decline in Capability}

A second requirement for a 'grievous and irremediable medical condition' is that the person must be 'in an advanced state of irreversible decline in capability'. ${ }^{156}$ Again, there are no court decisions that consider the criterion, ${ }^{157}$ and there are several aspects that are potentially unclear: ${ }^{158}$ does the decline relate to cognitive as well as physical function; does it relate to stabilised as well as ongoing declines in capability? The latter uncertainty is significant, for example, to individuals who have had a precipitous decline in capability (such as from a previous traumatic injury) but who have stabilised. Downie and Chandler argue that such a person would satisfy the criterion, ${ }^{159}$ although we note that this interpretation is somewhat broader than the wording in the glossary that accompanied Bill C-14. The glossary

153 In other words, if the government had intended for 'incurable' to mean only by means that a person found acceptable, the government would have specified this in the provision itself: see discussion in IRPP Report (n 131) 16-19.

154 Ibid. Downie and Chandler take the view that this criterion should be interpreted as in the professional opinion of the medical or nurse practitioner, the person cannot be cured by means acceptable to that person': at 17. In other words, a medical practitioner has concluded that there are no clinical options that would satisfy the individual's assessment of what is acceptable to them. Downie and Chandler raise a number of grounds for this including that such an approach is consistent with the position taken by the Supreme Court in Carter, and reflects the position taken by the Canadian Minister of Health and Senior Counsel for the Department of Justice when C-14 was before the Parliament: IRPP Report (n 131)18. The Minister of Health and Senior Counsel for the Department of Justice both stated when appearing before the Senate that 'incurable' should be interpreted as meaning by any means acceptable to the patient: Canada, Parliamentary Debates, Senate, 1 June 2016, 766 (Dr Jane Philpott) <https://sencanada. ca/Content/SEN/Chamber/421/Debates/pdf/041db_2016-06-01-e.pdf >; Evidence to Standing Senate Committee on Legal and Constitutional Affairs, Parliament of Canada, Ottawa, 6 June 2016, (Carole Morency, Joanne Klineberg) <www.parl.gc.ca/content/sen/committee/421/LCJC/52666-E.HTM>.

155 Bill C-7, $1^{\text {st }}$ Sess, $43^{\text {rd }}$ Parl, 2020, s 6 specifies that the exclusion of mental illness as a sole underlying condition will be automatically repealed two years after Bill C-7 received royal assent, ie on 17 March 2023. This grace period is intended to enable the government of Canada to commission an independent expert panel review of safeguards, protocols and guidance for MAiD and mental illness, and to allow the federal government and provincial and territorial governments enough time to develop these: Government of Canada, 'About Mental Illness and MAiD', Medical Assistance in Dying (Web Page, 30 June 2021) $<$ https://www.canada.ca/en/health-canada/services/medical-assistance-dying.html $>$.

156 Canadian Criminal Code, RSC 1985, c C-46, s 241.2(2)(b).

157 Note that one of the arguments in $\mathrm{Lamb}$ (now adjourned indefinitely) was that the applicant is precluded from MAiD because she was not in an advanced state of irreversible decline, which she argued infringes her section 7 Charter right to life, liberty, and security of the person: Lamb Claim, Supreme Court of British Columbia, No S-165851, 27 June 2016.

158 See IRPP Report (n 131) 23-6.

159 Ibid. 
states that a person must be 'in an irreversible decline towards death', which could suggest that the decline needs to be ongoing. ${ }^{160}$ There is also uncertainty around the standard against which the decline is judged. Downie and Chandler argue that assessment should be relative to the individual's prior capability rather than some objective standard. ${ }^{161}$

\section{(c) Intolerable Suffering}

The third requirement of 'grievous and irremediable medical condition' is that either the illness, disease, disability or state of decline must be causing enduring physical or psychological suffering that is intolerable to the person. ${ }^{162}$ The legislation frames this as a subjective inquiry; the provision refers to suffering that cannot be relieved under conditions the person considers acceptable.

\section{Voluntary Request}

Like the Model Bill and the WA Act, the Canadian Criminal Code includes a voluntary request as an eligibility criterion for MAiD. Section 241.2(1)(d) specifically notes that the request must not be made as a result of external pressure. A number of safeguards listed in sections 241.2(3) and 241.2(3.1) are designed to promote and ensure the voluntariness of the request. ${ }^{163}$

\section{Informed Consent}

The final eligibility criterion is that the person must 'give informed consent to receive medical assistance in dying after having been informed of the means that are available to relieve their suffering, including palliative care' and, for persons whose natural death has not become reasonably foreseeable, have been 'informed of the means available to relieve their suffering, including, where appropriate, counselling services, mental health and disability support services, community services and palliative care'. ${ }^{164}$ The legislation also requires that a person's request for MAiD must occur after they were informed by a medical or nurse practitioner that they have a grievous and irremediable medical condition. ${ }^{165}$

160 'Glossary', Department of Justice (Web Page, 7 July 2021) <https://www.justice.gc.ca/eng/cj-jp/ad-am/ glos.html\#archived $>$ (emphasis added).

161 IRPP Report (n 131) 23-6.

162 Canadian Criminal Code, RSC 1985, c C-46, s 241.2(2)(c).

163 The medical or nurse practitioner ('MAiD provider') must ensure the request is made in writing, signed and dated, and witnessed by one independent witness: ibid ss 241.2(3)(c), (3.1)(c). The MAiD provider must also inform the person they may withdraw their request at any time and in any manner: at ss 241.2(3)(d), (3.1)(d); and must give the person an opportunity to withdraw the request immediately before providing MAiD: at s 241(3.1)(k); except where the requirements for a final consent waiver or advance consent have been met under sections 241.2(3.2) or (3.5) respectively.

164 Ibid ss 241.2(1)(e), (3.1)(g).

165 Ibid s 241.2(3.1)(b)(ii). 
The Canadian Criminal Code requirement for informed consent intersects with provincial and territorial health care consent legislation ${ }^{166}$ and the common law. ${ }^{167}$ For example, for an adult to provide consent, British Columbia legislation imposes obligations on the health care provider to give the adult specified information including information about the person's condition, the nature of the proposed health care, the associated risks and benefits and alternative courses of health care. The health care provider must also give the adult an opportunity to ask questions and receive answers about the proposed health care. ${ }^{168}$

The common law has established that a health care provider seeking informed consent 'generally, should answer any specific questions posed by the patient as to the risks involved and should, without being questioned, disclose to him the nature of the proposed operation, its gravity, any material risks and any special or unusual risks attendant upon the performance of the operation' ${ }^{169}$

Across Canada, the various laws taken together require the individual requesting MAiD to have any questions they ask answered by their health care provider and to be informed: that they have a grievous and irremediable medical condition; of the nature of MAiD; of material, special or unusual risks, and potential benefits of MAiD and other available treatment options (including no treatment); and of available means to relieve suffering, including palliative care.

\section{COMPARATIVE ANALYSIS OF KEY ELIGIBILITY CRITERIA RELATING TO A PERSON'S MEDICAL CONDITION}

The purpose of this part is to undertake a comparative analysis of the eligibility criteria relevant to a person's medical condition and their access to VAD across the five models outlined above. The key criteria in this analysis are outlined below in Table 1, and the comparative issues that can have a significant impact on a person's access to VAD are explored below.

166 Consent to health care is a matter of provincial/territorial jurisdiction. See, eg, Adult Guardianship and Trusteeship Act, SA 2008, c A-4.2, s 1(d); Health Care (Consent) and Care Facility (Admission) Act, RSBC 1996, c 181, s 6; Health Care Directives and Substitute Health Care Decision Makers Act, SS 2015, c H-0.002, s 2(1); Health Care Directives Act, CCSM 1993, c H27, s 2; Health Care Consent Act, SO 1996, c 2, sch A s 4.

167 Reibl v Hughes [1980] 2 SCR 880. See College of Physicians and Surgeons of Alberta, 'Informed Consent for Adults' (Advice to the Profession, August 2019) <http://www.cpsa.ca/wp-content/ uploads/2016/02/AP_Informed-Consent-for-Adults.pdf >; College of Physicians and Surgeons of Alberta, 'Informed Consent' (Standards of Practice, June 2016) < http://www.cpsa.ca/standardspractice/informedconsent/>. See also Louise Bélanger-Hardy, 'Informed Choice in Medical Care' in Joanna N Erdman, Vanessa Gruben and Erin Nelson (eds), Canadian Health Law and Policy (LexisNexis, 5 ${ }^{\text {th }}$ ed, 2017) 329.

168 Health Care (Consent) and Care Facility (Admission) Act, RSBC 1996, c 181, s 6.

169 Hopp v Lepp [1980] 2 SCR 192, 210. 
Table 1 Comparative Table of Key Criteria Relevant to Medical Conditions and Eligibility for Access to $V A D^{170}$

\begin{tabular}{|c|c|c|c|c|c|}
\hline \multicolumn{6}{|l|}{ Capacity } \\
\hline & Victoria & Model Bill & $\begin{array}{l}\text { Western } \\
\text { Australia }\end{array}$ & Oregon & Canada \\
\hline $\begin{array}{l}\text { Nature of } \\
\text { capacity }^{171}\end{array}$ & $\begin{array}{l}\text { decision- } \\
\text { making } \\
\text { capacity in } \\
\text { relation to } \\
\text { voluntary } \\
\text { assisted dying }\end{array}$ & $\begin{array}{l}\text { decision- } \\
\text { making } \\
\text { capacity in } \\
\text { relation to } \\
\text { voluntary } \\
\text { assisted dying }\end{array}$ & $\begin{array}{l}\text { decision- } \\
\text { making } \\
\text { capacity in } \\
\text { relation to } \\
\text { voluntary } \\
\text { assisted dying }\end{array}$ & capable & $\begin{array}{l}\text { capable } \\
\text { of making } \\
\text { decisions with } \\
\text { respect to their } \\
\text { health }\end{array}$ \\
\hline \multicolumn{6}{|c|}{ Nature of medical condition ${ }^{172}$} \\
\hline & Victoria & Model Bill & $\begin{array}{l}\text { Western } \\
\text { Australia }\end{array}$ & Oregon & Canada \\
\hline $\begin{array}{l}\text { Prospect } \\
\text { of cure }\end{array}$ & incurable & incurable & - & $\begin{array}{l}\text { terminal } \\
\text { disease, that is } \\
\text { incurable and } \\
\text { irreversible }\end{array}$ & incurable \\
\hline $\begin{array}{l}\text { Stage and } \\
\text { nature of } \\
\text { condition }\end{array}$ & $\begin{array}{l}\text { advanced and } \\
\text { progressive }\end{array}$ & $\begin{array}{l}\text { advanced and } \\
\text { progressive }\end{array}$ & $\begin{array}{l}\text { advanced and } \\
\text { progressive }\end{array}$ & - & $\begin{array}{l}\text { serious; } \\
\text { advanced state } \\
\text { of irreversible } \\
\text { decline in } \\
\text { capability }\end{array}$ \\
\hline $\begin{array}{l}\text { Prospect } \\
\text { and } \\
\text { timing of } \\
\text { death }\end{array}$ & $\begin{array}{l}\text { will cause } \\
\text { death and this } \\
\text { is expected } \\
\text { within weeks } \\
\text { or months, } \\
\text { not exceeding } \\
6 \text { months or } \\
12 \text { months } \\
\text { for neuro- } \\
\text { degenerative } \\
\text { conditions }\end{array}$ & $\begin{array}{l}\text { will cause } \\
\text { death }\end{array}$ & $\begin{array}{l}\text { will on balance } \\
\text { of probabilities } \\
\text { cause death } \\
\text { within } 6 \text { months } \\
\text { or } 12 \text { months } \\
\text { for neuro- } \\
\text { degenerative } \\
\text { conditions }\end{array}$ & $\begin{array}{l}\text { will, within } \\
\text { reasonable } \\
\text { medical } \\
\text { judgment, } \\
\text { produce } \\
\text { death within } 6 \\
\text { months }\end{array}$ & - \\
\hline
\end{tabular}

170 For ease of presentation, this table includes only the words in the various legislation and does not include a discussion of how particular concepts have been interpreted.

171 For the purpose of this article, the added complexity of whether capacity is assessed only at the time of a request for $\mathrm{VAD}$, or also at the time of administration of $\mathrm{VAD}$, is not separately considered.

172 Although some jurisdictions use more precise terminology, such as 'disease, illness or medical condition' (Victorian Act 2017 (Vic) s 9(1)(d)), in this table the phrase 'medical condition' is employed for simplicity. 


\begin{tabular}{|c|c|c|c|c|c|}
\hline $\begin{array}{l}\text { Specific } \\
\text { statement } \\
\text { about } \\
\text { mental } \\
\text { illness }\end{array}$ & $\begin{array}{l}\text { mental illness } \\
\text { alone is not } \\
\text { eligible }\end{array}$ & - & $\begin{array}{l}\text { mental illness } \\
\text { alone is not } \\
\text { eligible }\end{array}$ & $\begin{array}{l}\text { ineligible if } \\
\text { suffering from } \\
\text { a psychiatric or } \\
\text { psychological } \\
\text { disorder or } \\
\text { depression } \\
\text { causing } \\
\text { impaired } \\
\text { judgment }\end{array}$ & $\begin{array}{l}\text { mental illness } \\
\text { is not an } \\
\text { illness, disease } \\
\text { or disability for } \\
\text { the purpose } \\
\text { of assessing } \\
\text { the eligibility } \\
\text { criteria }\end{array}$ \\
\hline \multicolumn{6}{|l|}{ Suffering } \\
\hline & Victoria & Model Bill & $\begin{array}{l}\text { Western } \\
\text { Australia }\end{array}$ & Oregon & Canada \\
\hline $\begin{array}{l}\text { Nature } \\
\text { and } \\
\text { source of } \\
\text { suffering }\end{array}$ & $\begin{array}{l}\text { medical } \\
\text { condition } \\
\text { is causing } \\
\text { suffering to } \\
\text { the person } \\
\text { that cannot be } \\
\text { relieved in a } \\
\text { manner that } \\
\text { the person } \\
\text { considers } \\
\text { tolerable }\end{array}$ & $\begin{array}{l}\text { medical } \\
\text { condition } \\
\text { is causing } \\
\text { intolerable } \\
\text { and enduring } \\
\text { suffering } \\
\text { (subjective, } \\
\text { includes } \\
\text { suffering from } \\
\text { treatment } \\
\text { and can be } \\
\text { physical, } \\
\text { psychological } \\
\text { and existential) }\end{array}$ & $\begin{array}{l}\text { medical } \\
\text { condition } \\
\text { is causing } \\
\text { suffering to } \\
\text { the person } \\
\text { that cannot be } \\
\text { relieved in a } \\
\text { manner that } \\
\text { the person } \\
\text { considers } \\
\text { tolerable }\end{array}$ & - & $\begin{array}{l}\text { medical } \\
\text { condition } \\
\text { or state of } \\
\text { decline causes } \\
\text { the person } \\
\text { enduring } \\
\text { physical or } \\
\text { psychological } \\
\text { suffering that } \\
\text { is intolerable } \\
\text { to them and } \\
\text { that cannot be } \\
\text { relieved under } \\
\text { conditions that } \\
\text { they consider } \\
\text { acceptable }\end{array}$ \\
\hline
\end{tabular}

\section{A Prospect and Timing of Death}

There are two key points in relation to the prospect and timing of death required under the VAD models. First, as noted in Table 1, the time expected to death varies. Some models specify a time limit: 6 months in Oregon, ${ }^{173}$ or 6 or 12 months depending on the medical condition in Victoria and Western Australia. ${ }^{174}$ In contrast, the Model Bill specifies no time limit or other temporal restriction on eligibility, but does require that a person has a condition that will cause death. ${ }^{175}$ The broadest approach is the amended Canadian law, which does not require temporal proximity and in some cases permits access for those without an expected

173 Oregon Act, Or Rev Stat § 127.800(12) (1994).

174 Victorian Act 2017 (Vic) ss 9(1)(d)(iii), 9(4); WA Act 2019 (WA) s 16(1)(c)(ii).

175 White and Willmott, 'Model Bill' (n 21) $21 \mathrm{cl}$ 9(e)(ii) simply states that the medical condition 'will cause death'. 
death. ${ }^{176}$ Although the operation in practice of these different legal approaches will be potentially qualified by interaction with other eligibility criteria, the criterion relating to prospect and timing of death plays a significant role in controlling access to VAD.

Second, there is also variability in wording about the level of certainty a doctor must have, or the 'standard of proof' that they must apply, in determining whether death will occur within that specified time. Formulations vary, with judgments about death to be made based on what is 'expected' (Victoria), ${ }^{177}$ estimated to occur on 'the balance of probabilities' (Western Australia) ${ }^{178}$ or assessed using 'reasonable medical judgment' (Oregon). ${ }^{179}$ Of these three jurisdictions, perhaps most noteworthy is the Western Australian choice to use 'balance of probabilities'. This terminology was a considered departure from the Victorian drafting ('expected'), yet parliamentary debates suggest that the standard in Western Australia is not lower than under the Victorian Act. ${ }^{180}$ Instead, the Western Australian government considered that the 'balance of probabilities' test was adopted because it is easily understood by clinicians and is a concept which 'provides the greatest clarity and most utility' ${ }^{181}$ All provide some discretion for doctors in determining prognosis, no doubt recognising the known difficulty of prognostication in relation to death. This was perhaps most explicitly recognised in the Canadian legislation between 2016 and 2021, which permitted a doctor to conclude that a person's death is reasonably foreseeable (an eligibility criterion at the time) 'without a prognosis necessarily having been made as to the specific length of time that they have remaining'. ${ }^{182}$

\section{B Suffering}

The models analysed also display significant variation in the level of suffering which must be experienced before a person is able to access VAD. There are three different thresholds of suffering across the five models of VAD. The first, the Oregon model, does not impose a suffering criterion (although the statute is worded to require a person to be 'suffering from a terminal disease'). ${ }^{183}$ Under the Victorian Act and WA Act, a person must be experiencing suffering, and this must not be able to 'be relieved in a manner that the person considers tolerable' ${ }^{184}$ The Canadian Criminal Code and the Model Bill contain the highest threshold, requiring that a

176 Canadian Criminal Code, RSC 1985, c C-46, s 241.2(2). Note though that whether a person's natural death has become reasonably foreseeable is relevant to which set of procedural safeguards must be followed before a person is eligible to access MAiD: at s 241.2 (3), (3.1).

177 Victorian Act 2017 (Vic) s 9(1)(d)(iii).

178 WA Act 2019 (WA) s 16(1)(c)(ii).

179 Oregon Act, Or Rev Stat § 127.800(12) (1994).

180 Western Australia, Parliamentary Debates, Legislative Council, 26 Nov 2019, 9196 (Stephen Dawson).

181 Ibid.

182 Canadian Criminal Code, RSC 1985, c C-46, s 241.2(2)(d), as repealed by Bill C-7, $1^{\text {st }}$ Sess, 43 ${ }^{\text {rd }}$ Parl, 2020, s 1(1).

183 Oregon Act, Or Rev Stat $§ 127.805(1)$ (1994). Suffering here is used as meaning having a terminal illness.

184 Victorian Act 2017 (Vic) s 9(1)(d)(iv); WA Act 2019 (WA) s 16(1)(c)(iii). 
person be experiencing suffering that is 'intolerable' to them, is enduring, and (in Canada) that 'cannot be relieved under conditions that they consider acceptable'. ${ }^{185}$

Another key difference across models is the cause of the suffering. Under the Victorian Act and the WA Act, the terminal medical condition must be the cause of a person's suffering to be eligible for VAD. ${ }^{186}$ The Model Bill additionally recognises that the treatment for that condition may also be considered in assessing a person's suffering. ${ }^{187}$ The Canadian approach is different again, as either the person's 'illness, disease or disability' or their 'state of decline' (that is, their advanced state of irreversible decline in capability) can be the cause of their suffering. ${ }^{188}$

Despite these differences, in the four models where suffering is required, there are also a number of similarities. One is that suffering is assessed subjectively by the person seeking VAD in all models. ${ }^{189}$ This may mean that the differences in the suffering thresholds described above are less significant in practice if the requisite suffering is to be determined subjectively. Another is that suffering is broadly understood to encompass not only physical pain, but also psychological and existential suffering. ${ }^{190}$

\section{Access to VAD and Mental Illness}

The VAD models differ in their treatment of the issue of mental illness. Four jurisdictions specifically address the impact of mental illness on possible access to VAD. The Victorian Act and the WA Act specifically state that mental illness on its own will not be sufficient to render a person eligible for VAD ${ }^{191}$ However, a person with a mental illness who also suffers from another medical condition that otherwise meets the criteria is still capable of qualifying under these models. The Canadian Criminal Code states (until the sunset clause takes effect on 17 March 2023) that mental illness cannot be considered to be an illness, disease or disability for the purposes of assessing whether the patient has a serious and incurable illness, disease or disability. But, similar to the two Australian models, the Canadian law does not exclude access if mental illness is comorbid with another serious and incurable condition. The Oregon Act makes specific mention of mental illness, precluding access to VAD if a person is suffering from a psychological or psychiatric disorder or depression that causes impaired judgment. Once the person

185 Canadian Criminal Code, RSC 1985, c C-46, s 241.2(2)(c); White and Willmott, 'Model Bill' (n 21$) 21 \mathrm{cl}$ 9(e)(iii).

186 Victorian Act 2017 (Vic) s 9(1)(d)(iv); WA Act 2019 (WA) s 16(1)(c)(iii).

187 White and Willmott, 'Model Bill' (n 21) $21 \mathrm{cl} 10(2)(\mathrm{b})$.

188 Canadian Criminal Code, RSC 1985, c C-46, s 241.2(2)(c).

189 In Victoria and Western Australia, whether the suffering can be relieved in a manner that the person considers tolerable is subjectively assessed: Victorian Act 2017 (Vic) s 9(1)(d)(iv); WA Act 2019 (WA) s 16(1)(c)(iii). Under the Model Bill and in Canada, it is the suffering itself that is subjectively assessed by a person to be intolerable (as well as the proposed methods of relief, in Canada): White and Willmott, 'Model Bill' (n 21) 21 cl 10(2)(a); Canadian Criminal Code, RSC 1985, c C-46, s 241.2(2)(c).

190 Canada includes 'physical or psychological suffering': Canadian Criminal Code, RSC 1985, c C-46, s 241.2(2)(c), whereas the Model Bill includes 'physical, psychological and existential suffering': White and Willmott, 'Model Bill' (n 21) $21 \mathrm{cl}$ 10(2)(c).

191 Victorian Act 2017 (Vic) s 9(2); WA Act 2019 (WA) s 16(2). 
has been clinically assessed and determined not to have impaired judgment, ${ }^{192}$ the person may access VAD if they have a terminal illness. Only the Model Bill does not explicitly address mental illness. However, the way in which its other eligibility criteria are drawn makes it very unlikely that access only on the basis of mental illness would occur. ${ }^{193}$

\section{Impact of Refusing Potentially Life Sustaining Treatment}

A refusal of potentially life sustaining treatment has relevance for two statutory criteria: an 'incurable' condition, and a condition that will 'cause death'. This issue is handled differently under the various models, and these differences are significant in terms of access to VAD. First, can a person be said to have an 'incurable' condition if they are refusing treatment that presents a reasonable prospect of a cure? The meaning of 'incurable' and the impact of treatment refusals is not explained in the legislation of the four jurisdictions which use this pivotal criterion.

In Victoria, extrinsic material states that whether a person's medical condition is incurable is a medical assessment based on available treatments and a person will not be eligible if they are refusing treatment for an otherwise curable condition. ${ }^{194}$ The Model Bill uses the same language as the Victorian Act and would be interpreted in the same way. By contrast, in Canada, the practice appears to be that incurability is being determined having regard to treatments acceptable to the patient, although there are arguments that can be made to the contrary that treatment refusals should not be considered ${ }^{195}$ There is no available material to assist in the interpretation of this term in the Oregon Act. ${ }^{196}$ Refusal of potentially life sustaining treatment is a scenario which is likely to occur in practice. It would be desirable for legislation to give clear guidance to doctors about whether patients can make their condition incurable, and become eligible for VAD, through treatment refusal.

The impact of refusals of potentially life sustaining treatment generally appears clearer in relation to the criterion of whether a medical condition will cause death, and within a certain period of time. In Victoria, extrinsic materials show that the requirement that a condition will cause death within 6 or 12 months will take account of the right to refuse treatments the person finds unacceptable. ${ }^{197}$ Identical language is used in the WA Act, so that legislation is likely to be interpreted similarly. The Model Bill makes this explicit with a provision clarifying that whether a medical condition will cause death 'is to be determined by reference to available medical

192 Oregon Act, Or Rev Stat $§ 127.825$ (1994).

193 This is because in general mental illnesses are not terminal conditions. The majority of mental illnesses are cyclical, and do not progress naturally towards death. Note, however, the consideration of potential eligibility for access to VAD for anorexia, given that it is a mental illness which may be said in extreme cases to cause death: see White et al, 'Who is Eligible for VAD?' (n 19).

194 Explanatory Memorandum, Voluntary Assisted Dying Bill 2017 (Vic) 3-4 cl 9. See discussion above at Part II(B)(2).

195 See discussion above at Part II(F)(2)(a).

196 See discussion above at Part II(E)(2).

197 Explanatory Memorandum, Voluntary Assisted Dying Bill 2017 (Vic) 3-4 cl 9. 
treatment that is acceptable to the person' ${ }^{198}$ The Oregon Act, however, provides no guidance on this issue for courts or medical practitioners.

Significantly, in Western Australia, the government specifically chose not to include 'incurable' as a legislative criterion. This was because it was considered implicit in the criterion of a medical condition which is advanced, progressive and will cause death. It was also considered inappropriate to require a person to exhaust all treatment options when there is a long-established right to refuse treatment. ${ }^{199}$ Although members of both Houses of Parliament sought to amend the VAD Bill (WA) to include 'incurable' as a criterion, ${ }^{200}$ these amendments were rejected ${ }^{201}$ and not included in the WA Act. Drawing on the analysis above, this means that in Western Australia, a person with a curable or treatable condition may be able to refuse treatment and become eligible to access VAD because they then (after treatment refusal) have a condition that will cause death. Examples given in parliamentary debates were an operable tumour ${ }^{202}$ and gangrene which was curable with amputation. ${ }^{203}$

This is in contrast to the Victorian Act and the Model Bill where incurability in the eligibility criteria functions as a limit on when access to VAD may be possible. Under those models, a person with a curable condition (such as an operable tumour or gangrene) will not be eligible for VAD, even if the person refuses the suggested treatment for that condition, because their condition will not be medically assessed to be 'incurable'. Some Members of Parliament in Western Australia have expressed concern that omitting incurability widens the category of people who may have access to VAD in that State..$^{204}$

\section{IMPLICATIONS OF COMPARATIVE ANALYSIS FOR DESIGN OF VAD REGULATION}

The above analysis has demonstrated some important similarities and differences across five models of VAD laws. The purpose of eligibility criteria is to

198 White and Willmott, 'Model Bill' (n 21) $21 \mathrm{cl}$ 10(1).

199 Western Australia, Parliamentary Debates, Legislative Assembly, 5 September 2019, 6586 (Mark McGowan); Western Australia, Parliamentary Debates, Legislative Council, 26 November 2019, 9200 (Stephen Dawson).

200 Western Australia, Parliamentary Debates, Legislative Assembly, 5 September 2019, 6601 (Margaret Quirk); Western Australia, Parliamentary Debates, Legislative Council, 26 November 2019, 9199 (Nick Goiran).

201 Western Australia, Parliamentary Debates, Legislative Assembly, 5 September 2019, 6605; Western Australia, Parliamentary Debates, Legislative Council, 26 November 2019, 9202.

202 Western Australia, Parliamentary Debates, Legislative Assembly, 5 September 2019, 6586 (Michael Nahan).

203 Western Australia, Parliamentary Debates, Legislative Assembly, 5 September 2019, 6603-4 (Margaret Quirk); Western Australia, Parliamentary Debates, Legislative Council, 26 November 2019, 9199 (Nick Goiran).

204 See, eg, Western Australia, Parliamentary Debates, Legislative Assembly, 5 September 2019, 6602 (David Honey); Western Australia, Parliamentary Debates, Legislative Council, 26 November 2019, 9200 (Michael Mischin). 
draw lines determining who should be able to access VAD. Within the five models considered, when analysing the criteria as a whole, it is apparent that these lines are drawn in quite different places. Canada has the most permissive eligibility criteria in its MAiD law, especially since Bill C-7 removed the reasonable foreseeability criterion introduced in Bill C-14. At the other end of the spectrum, the Victorian Act, WA Act and Oregon Act are much more conservative. ${ }^{205}$ This comparative analysis has important implications for the design of VAD regulatory systems more broadly. This section shifts beyond the specifics of these legal models and considers the wider questions they give rise to for policymakers and legislators proposing laws in this area.

\section{A Challenge of Translating Policy Goals into Legislation}

One implication is the long-standing policy challenge of using words in legislation to accurately reflect a stated policy intent. The translation of broader social objectives into concrete legal rules is a challenging exercise. ${ }^{206}$ Problems can arise not only in the selection of words, but also their interpretation, both by the courts and by those at the coalface who are charged with implementing the law. An ideal law is precise and can be applied consistently in relation to a wide variety of situations to which the law is intended to apply. ${ }^{207}$ But legal rules are 'inherently indeterminate', both because language is imprecise, and because they are subject to interpretation by others. ${ }^{208}$

Precision in wording can require compromises in terms of the congruence of the law with the policy goals underpinning it. An example of this is the imposition of a specified time limit to death in Victoria, Western Australia and Oregon. ${ }^{209}$ An advantage of such an approach is it gives a concrete frame of reference for doctors and others to use when determining eligibility (we put aside for the moment difficulties of prognostication ${ }^{210}$ ). However, a precise time limit could be seen as an inadequate proxy for the wider policy intent: namely, identifying the cohort of people (those who are dying) for whom VAD should be made available. It can also

205 This finding resonates with claims made by the Victorian government at the time of the Victorian Act 2017 (Vic) passing: see Andrews Media Release (n 32).

206 Karen Yeung, 'Regulating Assisted Dying' (2012) 23(2) King's Law Journal 163, 168-70. See also White et al, 'Does the VAD Act (Vic) Reflect Its Stated Policy Goals?' (n 57).

207 Law Council of Australia, 'Rule of Law Principles' (Policy Statement, March 2011) <https://www. lawcouncil.asn.au/docs/f13561ed-cb39-e711-93fb-005056be13b5/1103-Policy-Statement-Rule-of-LawPrinciples.pdf $>$.

208 Yeung (n 206) 169. See also Julia Black, Rules and Regulators (Clarendon Press, 1997).

209 In Victoria and Western Australia, a person must be suffering from a condition which is expected to cause death within 6 months, or 12 months if the condition is neurodegenerative: Victorian Act 2017 (Vic) ss 9(1)(d)(iii), 9(4); WA Act 2019 (WA) s 16(1)(c)(ii). In Oregon, death must be anticipated within 6 months: Oregon Act, Or Rev Stat $§ 127.800(12)$ (1994). In contrast, the Canadian Criminal Code includes no such time limit.

210 Joanne Lynn et al, 'Defining the "Terminally Ill”: Insights from SUPPORT' (1996) 35(1) Duquesne Law Review 311; Eric Chevlen, 'The Limits of Prognostication' (1996) 35(1) Duquesne Law Review 337; James Downar et al, "The "Surprise Question" for Predicting Death in Seriously Ill Patients: A Systematic Review and Meta-Analysis' (2017) 189(13) Canadian Medical Association Journal E484; Paul Glare et al, 'Predicting Survival in Patients with Advanced Disease' (2008) 44(8) European Journal of Cancer $1146,1147$. 
operate arbitrarily, in that there may be very little to distinguish between a person who is expected to die within the specified time limit, and those with similar conditions whose prognosis is slightly longer. Rigidly applied, it also gives rise to injustices in some situations, such as where people are terminally ill and suffering, but are forced to continue to suffer until they are close enough to death to meet the eligibility time period.

An alternative is to use words that better reflect the policy intent but may be less precise. '[N]atural death' being 'reasonably foreseeable' was an example of such an approach in Canada. ${ }^{211}$ Although this drafting technique avoids the pitfalls of arbitrary time limits, it greatly increases the uncertainty surrounding the class of person to whom the legislation applies, as the extensive debate that has occurred in Canada about this terminology demonstrates. Such imprecision is problematic for doctors and others making assessments about eligibility for VAD ${ }^{212}$ This uncertainty can only be definitively resolved in an individual case through court decision, which is a costly and slow process, and judicial consideration of legislative terms can still fail to provide useful guidance in practice for other cases. Such uncertainty could, however, potentially be reduced through the use of other regulatory tools, such as guidelines or policy, to supplement law and provide greater clarity.

\section{B Operation of Eligibility Criteria Is Shaped by Wider VAD System}

A second implication for VAD regulation is that the operation of eligibility criteria inevitably interacts with how the wider VAD system is designed. One illustration of this is the criterion of capacity. All models require that a person must have capacity at the point access to VAD is granted, and the concept of capacity is defined in broadly similar terms. However, differences in the way VAD is administered have significant effects on the timing of these capacity assessments, and thus on who may access VAD.

For Victoria, Western Australia and Oregon, capacity is required at the point of the final request for VAD. Where VAD occurs by self-administration, this means that capacity is last assessed when the person is approved to receive the VAD medication. ${ }^{213}$ But this medication can be taken later, without medical or other supervision, and there is no testing of capacity at that point when the medication is actually taken. By contrast, where practitioner administration is authorised in Victoria and Western Australia, a person must have capacity at the time of

211 Canadian Criminal Code, RSC 1985, c C-46, s 241.2(2)(d), as repealed by Bill C-7, $1^{\text {st }}$ Sess, $43^{\text {rd }}$ Parl, 2020, s 1(1).

212 Ministerial Advisory Panel on Voluntary Assisted Dying, Department of Health and Human Services (Vic), Interim Report of the Ministerial Advisory Panel: Consultation Overview, Voluntary Assisted Dying Bill (Report, April 2017) 21-3.

213 In terms of the final stage in the self-administration process where there is a legislative requirement to have capacity: in Victoria, this is the point at which the medical practitioner applies for a selfadministration permit on behalf of a person: Victorian Act 2017 (Vic) s 47(3)(a). In Western Australia, this is at the point of final request: WA Act 2019 (WA) s 51(3)(f)(i). In Oregon, this is immediately prior to writing a prescription: Oregon Act, Or Rev Stat $\S 127.830$ (1994). See also the definition of 'qualified patient': Oregon Act, Or Rev Stat § 127.800(11) (1994). 
administering the medication, ${ }^{214}$ because the last request is made at the same time as VAD is administered.

For Canada, the position is similar to the extent that capacity must be assessed both when making a request for MAiD, and, with two exceptions, immediately before it is provided ${ }^{215}$ this latter point being at the time of administering the medication for practitioner administration and when prescribing or providing the medication for self-administration. However, if a person's death is reasonably foreseeable, there is an exception to this requirement of capacity at the time of MAiD provision if the conditions for a final consent waiver are met. ${ }^{216}$ Whether a person's natural death is reasonably foreseeable or not, there is also an exception to the requirement of capacity at the time of MAiD provision for provider-administered MAiD where self-administration has failed and the conditions for an 'advance consent' are met. ${ }^{217}$ Under the Model Bill, capacity must be present during assessment and when VAD is provided. ${ }^{218}$ VAD under this latter model, whether by self-administration or practitioner administration, is always medically supervised ${ }^{219}$ and there is a final check of capacity at that point. ${ }^{220}$ In short, although all models require a person to have capacity to request VAD, the overarching design of the VAD law results in this having different implications for those different models.

Another illustration is that there are sometimes fluid boundaries between whether a matter is stated to be a criterion of eligibility or a procedural step. It is possible conceptually for these parts of the legislation to be seen as distinct: one deals with the threshold question of access and the other relates to procedures that must be followed to receive access. However, these five models do reflect that some legislators have conceived certain aspects of their VAD law in different ways.

One example is the issue of 'informed consent'. This is stated to be part of the eligibility criteria in Canada, but not in the Australian models nor in Oregon. However, the need to provide information and ensure it is understood is an important part of the procedural steps outlined in these latter jurisdictions. Another example is that the requirement that a decision be made freely and voluntarily is a criterion of eligibility in the Model Bill, the WA Act, the Canadian Criminal Code and the Oregon Act, but in Victoria is tested at various points as a procedural issue. Thirdly, that the decision is enduring is a condition of eligibility in the Model Bill and the WA Act, but is tested through process in the other jurisdictions.

In practice, it may not be significant whether various issues are part of the threshold question of access or tested during various procedural steps. This may simply reflect a preference of legislators in terms of drafting or their understanding

214 Victorian Act 2017 (Vic) ss 64(1)(b), 65(2)(a)(i); WA Act 2019 (WA) s 59(5)(a).

215 Canadian Criminal Code, RSC 1985, c C-46, s 241.2(3)(a), referring to the eligibility criteria in s $241.2(1)$, including capacity in s $241.2(1)(b)$.

216 Ibid s 241.2(3.2) ('final consent - waiver').

217 Ibid s 241.2(3.5) ('advance consent - self-administration').

218 White and Willmott, 'Model Bill' (n 21) $23 \mathrm{cl}$ 16, $25 \mathrm{cl}$ 21, $28 \mathrm{cl}$ 26(2), 30-2 cls 29(1)(a)(ii),29(2)(a)(iii), $30(1)(b), 32(2)(a)$.

219 Ibid 19-20 cl 6.

220 Ibid 31-3 cls 30(1)(b), 32(2)(a), 33(3). 
of how conceptually these matters contribute to the VAD system as safeguards. However, this distinction could potentially be significant, so reflection on whether a safeguard is better conceived as an eligibility criterion or process matter is important. For example, if the enduring nature of a person's request is imputed on the basis of them requesting VAD at three points in the process, this is different from requiring an enduring decision as a formal part of eligibility. A person could be prevaricating regularly over time and be regarded as not having made an enduring and settled decision to seek VAD, yet still have three points in time at which they were requesting it.

A final point to note about the operation of eligibility criteria is that it is shaped not only by the design of the wider VAD system, but it is also affected by how the system functions in practice. Thus, while a particular person may meet the legal eligibility criteria for VAD, their access to VAD depends upon a system that facilitates that, including access to willing doctors. ${ }^{221}$

\section{Regulation Operates Holistically}

A third design point to make is that a system of regulation operates holistically. This means that looking at a single aspect of the eligibility criteria without understanding its role in the wider framework can be misleading. That is, it is important to examine eligibility criteria cumulatively and in context. This is the intention of the legislators in constructing the criteria in this way and this has significant implications for who can access VAD. As described above, the Model Bill provides a good example of this: if the focus is restricted to the fact that the Bill does not impose a time limit until death, it may seem to be very broadly drafted. But when aggregated with the requirement for a medical condition that is incurable, advanced and progressive, the scope for access to VAD is considerably narrowed. This is not to make the case for wide or narrow criteria for access to $\mathrm{VAD}$, but to argue for a holistic assessment of cumulative eligibility criteria to properly represent the intent and scope of a VAD law. ${ }^{222}$

Taking a holistic view is also an important consideration more generally when designing VAD regulation. While it may be politically attractive to add numerous safeguards to VAD legislation, including in the eligibility criteria, there is a risk of what we have called elsewhere 'policy drift by a thousand cuts' if the cumulative effect of these individual safeguards is not properly considered. ${ }^{223}$ For example, it is possible that a series of provisions designed to make VAD legislation safe, when aggregated, can in fact make access to VAD cumbersome or even unworkable.

221 We thank an anonymous reviewer for this point.

222 This does not always happen: see, eg, comments of Archbishop Aspinall about the Model Bill (n 21) which wrongly suggest it would permit persons with dementia to access VAD in Jamie Walker, 'Euthanasia Law A Life of its Own', The Australian (online, 31 August 2019) < https://www.theaustralian. com.au/nation/euthanasia-law-a-life-of-its-own/news-story/86c0fdfa059b99893526f65f5a0e7987>.

White et al, 'Does the VAD Act (Vic) Reflect Its Stated Policy Goals?' (n 57) 451. 


\section{CONCLUSION}

The purpose of eligibility criteria is to determine who will and will not be permitted to access VAD. As such, they play an important role in determining the scope of VAD laws, and are (rightly) heavily debated in parliaments considering reform. This article has analysed the key eligibility criteria relevant to the medical condition of a person seeking access to VAD under five different legal models. Three of the models were Australian: the recently enacted legislation in Victoria and Western Australia, along with a Model Bill under consideration in Queensland. The remaining two VAD models analysed were from the common law jurisdictions of Oregon and Canada.

Comparative analysis is an established part of law reform processe ${ }^{224}$ and so the evaluation undertaken above not only sheds light on how those laws should operate locally but also provides insights for other jurisdictions considering VAD reforms. Regulation permitting VAD remains relatively novel worldwide, so analysis of these individual models provides important insight for parliamentary committees, law reform bodies and parliamentarians. The article has also considered what global lessons might be learned from how these five models operate. The preceding section considered important implications for designing VAD regulation generally, such as how eligibility criteria intersect with other parts of the VAD laws and the importance of evaluating criteria holistically to understand properly their legal effect.

The analysis undertaken in this article also provides a platform for the next article in this series. Having explained and analysed the relevant legal criteria for accessing VAD in the five jurisdictions, the second article will consider how these criteria will apply to specific medical conditions. What medical conditions might meet the criteria for access to VAD, and at what point in an illness trajectory will access be possible? This is different from the more conceptual and legal analysis already undertaken, but is critically important for optimal law reform. If parliamentarians intend to grant or deny access to VAD for particular medical conditions, then concrete testing of proposed eligibility criteria in relation to those conditions is essential. 